\title{
Modeling sub-boreal forest canopy bulk density in Minnesota, USA, using synthetic aperture radar and optical satellite sensor data
}

Peter T. Wolter ${ }^{1 *}$, Jacob J. Olbrich ${ }^{1}$ and Patricia J. Johnson ${ }^{2}$

\begin{abstract}
Background: National estimates of canopy bulk density $\left(C B D ; \mathrm{kg} \mathrm{m}^{-3}\right)$ for fire behavior modeling are generated and supported by the LANDFIRE program. However, locally derived estimates of CBD at finer scales are preferred over national estimates if they exist, as the absolute accuracy of the LANDFIRE CBD product is low and varies regionally. Active sensors (e.g., lidar or radar) are better suited for this task, as passive sensors are ill equipped to detect differences among key vertical fuel structures, such as coniferous surface fuels ( $\leq 2 \mathrm{~m}$ high) and canopy fuels above this threshold - a key categorical fuel distinction in fire behavior modeling. However, previous efforts to map CBD using lidar sensor data in the Superior National Forest (SNF) of Minnesota, USA, yielded substandard results. Therefore, we use a combination of dormant-season synthetic aperture radar (SAR) and optical satellite sensor data to (1) expand detectability of coniferous fuels among mixed forest canopies to improve the accuracy of CBD modeling and (2) better understand the influence of surface fuels in this regard. Response variables included FuelCalc output and indirect estimates of maximum burnable fuel based on canopy gap fraction (CGF) measured at ground level and $2 \mathrm{~m}$ above ground level.

Results: SAR variables were important predictors of CBD and total fuel density (TFD) in all independent model calibrations with ground data, in which we define TFD as the sum of CBD and primarily live coniferous surface fuel density (SFD) 0 to $2 \mathrm{~m}$ above ground. Exploratory estimates of TFD appeared biased to the presence of saplingstage conifer fuel on measures of CGF at the ground level. Thus, modeling efforts to calibrate SFD with satellite sensor data failed. Both CGF-based and FuelCalc-based field estimates of CBD yielded close unity with satellitecalibrated estimates, although substantial differences in data distributions existed. Estimates of CBD from the widest CGF zenith angle range ( 0 to $38^{\circ}$ ) correlated best with FuelCalc-based CBD estimates, while both resulted in maximum biomass values that exceeded those considered typical for the SNF. Model results from the narrowest zenith angle range $\left(0\right.$ to $\left.7^{\circ}\right)$ produced estimates of $C B D$ that were more in line with values considered typical. LANDFIRE's estimates of CBD were weakly, but significantly $(P=0.05)$, correlated to both narrow- and wide-angle CGF-based estimates of CBD, but not with FuelCalc-based estimates.
\end{abstract}

\footnotetext{
* Correspondence: ptwolter@iastate.edu

${ }^{1}$ Department of Natural Resource Ecology and Management, lowa State

University, 2310 Pammel Drive, Ames, IA 50011, USA

Full list of author information is available at the end of the article
}

\section{Springer Open}

(c) The Author(s). 2021 Open Access This article is licensed under a Creative Commons Attribution 4.0 International License, which permits use, sharing, adaptation, distribution and reproduction in any medium or format, as long as you give appropriate credit to the original author(s) and the source, provide a link to the Creative Commons licence, and indicate if changes were made. The images or other third party material in this article are included in the article's Creative Commons licence, unless indicated otherwise in a credit line to the material. If material is not included in the article's Creative Commons licence and your intended use is not permitted by statutory regulation or exceeds the permitted use, you will need to obtain permission directly from the copyright holder. To view a copy of this licence, visit http://creativecommons.org/licenses/by/4.0/. 
Conclusions: The combined use of field estimates of CBD, based on indirect measures of CGF according to Keane et al. (Canadian Journal of Forest Research 35:724-739, 2005), with SAR and optical satellite sensor data demonstrates the potential of this method for mapping CBD in the Upper Midwest, USA. Results suggested that the presence of live, coniferous surface fuels neither confounds remote detection nor precludes mapping of CBD in this region using SAR satellite sensor data, as C- and L-band idiosyncrasies likely limit the visibility of these smaller understory fuels from space. Nevertheless, research using direct measures of burnable SFD for calibrations with SAR satellite sensor data should be conducted to more definitively answer this remote detection question, as we suspect substantial bias among measures of CGF from ground level when estimating SFD as the difference between TFD and CBD.

Keywords: Canopy bulk density, Canopy gap fraction, FuelCalc, LANDFIRE, Satellite, Sub-boreal forest, Synthetic aperture radar, Upper Midwest

\section{Resumen}

Antecedentes: Las estimaciones nacionales sobre la densidad aparente (CBD; $\mathrm{kg} \mathrm{m}^{-3}$ ) para el modelado del comportamiento del fuego, son generados y apoyados por el programa LANDFIRE. Sin embargo, la CBD derivada de estimaciones locales a escalas más finas son preferidas a las nacionales (si estas existieran) dado que la precisión absoluta de LANDFIRE CBD es baja y varía regionalmente. Los sensores activos (i.e., Lidar o Radar) están mejor preparados para esta tarea, dado que los sensores pasivos están débilmente equipados como para detectar diferencias entre estructuras verticales de combustibles clave como los combustibles superficiales de coníferas ( $\leq 2$ $m$ de altura) y combustibles del dosel por encima de este límite, una categoría distintiva clave en el modelado del comportamiento del fuego. Sin embargo, esfuerzos previos para mapear CBD usando datos del sensor Lidar en el Bosque Nacional del Superior (SNF) de Minnesota, EEUU, dio resultados deficientes. Por ese motivo, usamos una combinación de datos de Radar de apertura sintética (SAR) para épocas de dormancia y de un sensor satelital óptico para (1) expandir la detectabilidad de combustibles de coníferas en doseles mixtos para mejorar la exactitud del modelo CBD, y (2) para entender mejor la influencia de los combustibles superficiales en ese aspecto. Las variables respuesta incluyeron la salida del FuelCalc y estimaciones indirectas de combustibles de máxima combustibilidad, basados en la fracción de apertura del dosel (CGF) medida a nivel del suelo y a dos metros sobre la superficie del suelo.

Resultados: Las variables SAR fueron importantes predictores de CBD y de la densidad total de los combustibles (TFD) en todas las calibraciones de modelos independientes con datos del suelo superficial, en los cuales definimos TFD como la suma de CBD y primariamente la densidad del combustible vivo superficial de coníferas (SFD) de 0 a $2 \mathrm{~m}$ por encima de la superficie del suelo. Las exploraciones estimativas de TFD aparecen como sesgadas hacia la presencia de combustible representado por plántulas de coníferas en mediciones de CGF a nivel del suelo. Entonces, los esfuerzos del modelado para calibrar SFD con datos de sensores de satélite fracasaron. Las estimaciones de ambos, CGF y de campo mediante FuelCalc sobre el CBD brindaron una gran paridad con las estimaciones calibradas de los satélites, aunque existieron diferencias sustanciales en la distribución de los datos. Las estimaciones de CBD desde el rango del ángulo zenital más ancho $\left(0\right.$ a $\left.38^{\circ}\right)$ se correlacionaron mejor con las estimaciones basadas en FuelCalc, mientras que ambas resultaron en estimaciones de biomasa máximos que excedieron a aquellos considerados típicos para la SNF. Los resultados de los modelos de rangos de ángulos zenitales más angostos $\left(0\right.$ a $\left.7^{\circ}\right)$ produjeron estimaciones de $C B D$ que estuvieron más en línea con los valores considerados típicos. Las estimaciones de CBD producidas por LANDFIRE fueron débiles, aunque correlacionadas significativamente $(P=0.05)$, con las estimaciones de CBD derivadas de ambos ángulos angostos y anchos de CGF, pero no con estimaciones basadas en FuelCalc. 
Conclusiones: El uso combinado de estimaciones de campo de CBD, basados en medidas indirectas de CGF de acuerdo con Keane et al. (Canadian Journal of Forest Research 35:724-739, 2005), con SAR y datos de sensores de satélite, demostraron el potencial de este método para mapear CBD en el Medio-Oeste Alto de los EEUU. Los resultados sugieren que la presencia de combustible vivo superficial de coníferas ni confunde a la detección remota ni excluye el mapeo de CBD en esta región usando datos de sensores satelitales, como las bandas idiosincráticas C y L pueden limitar la visibilidad, desde el espacio, de esos combustibles más pequeños. De todas maneras, la investigación usando de medidas directas de SFD combustible para calibraciones con datos del sensor del satélite SAR deben conducir a contestar definitivamente esta cuestión de la detección remota, dado que sospechamos un sesgo sustancial entre medidas de CGF a nivel del suelo cuando estimamos SFD como la diferencia entre TFD y CBD.

\section{Background}

Canopy bulk density (CBD) is routinely cited as a salient biophysical forest canopy fuel variable-along with canopy base height, stand height, and percent canopy cover-required for modeling crown fire behavior and risk (Finney 1998; Scott 1999; Keane et al. 2005; Keane et al. 2006; Krasnow et al. 2009; Engelstad et al. 2019). In this study, CBD represents burnable mass per unit canopy volume $\left(\mathrm{kg} \mathrm{m}^{-3}\right)$ available to crown fires, primarily live foliage (needles) and branches less than $3 \mathrm{~mm}$ in diameter and dead branches less than $6 \mathrm{~mm}$ in diameter (Van Wagner 1977; Alexander 1988; Finney 1998; Keane et al. 2005). Live broadleaf tree foliage is not considered critical canopy fuel due to low overall flammability (Van Wagner 1977). Thus, exclusion of broadleaf fuels from CBD calculations is standard practice (Cruz et al. 2003). Spatially explicit estimates of CBD, often used in modeling wildfire behavior (e.g., FARSITE; Finney 1998), are provided by the Landscape Fire and Resource Management Planning Tools (LANDFIRE) program (Reeves et al. 2009; Rollins 2009; www.landfire.gov). These CBD estimates are national in scope, calibrated using a combination of optical Landsat sensor data, US Forest Service Forest Inventory and Analysis (FIA) ground data, and the LANDFIRE reference database (Rollins 2009), which are then extrapolated to the landscape using sophisticated statistical and environmental modeling approaches (Keane et al. 2006). In this calibration process, certain assumptions regarding both the spatial and biophysical accuracy of FIA field plot data as well as the allometry used to determine CBD were adopted (Keane et al. 2006). With respect to FIA, recent work in Minnesota, USA, provides evidence to question some of the common assumptions regarding the combined use of Landsat and FIA for mapping biophysical forest structure information, especially spatial accuracy and suboptimal subplot design with regard to $30-\mathrm{m}$ satellite sensor data (Thapa et al. 2020). Regardless of the sources of mapping error, it is understood that the absolute accuracy of the LANDFIRE CBD data product varies regionally (Keane et al. 2006; Scott 2008; Krasnow et al. 2009) and should not replace locally derived fuel products if they exist at finer spatial scales (Keane et al. 2006), which is the pretext for this research.

While CBD is a salient variable for modeling crown fire behavior, it is also one of the most difficult parameters to measure accurately in the field (Alexander 1988; Keane et al. 2005). This is because the vertical distribution of biomass varies by conifer species, crown position, and shade tolerance and from stand to stand (Brown 1978; Keane et al. 2002; Keane et al. 2006). Moreover, according to Keane et al. (2005), various vertical average measures of CBD likely underestimate effective CBD fuel conditions, noting that a few patches of fuel having substantially higher biomass values than the vertical canopy average will sustain fire spread. Therefore, they included the maximum $\mathrm{CBD}$ among all $1-\mathrm{m}$ vertical layers as an important fuel variable to model, which we follow in this study. Equally vexing is the fact that key forest fuel properties (e.g., surface fuel, CBD, and canopy base height) are practically impossible to detect or distinguish via optical satellite sensors (e.g., Landsat-8 and Sentinel-2). Logical options suggested for remote detection of vertical canopy structures include lidar and radar (Keane et al. 2001; Keane et al. 2006).

Efficient methods for the calculation of CBD from indirect measurement of canopy gap fraction (CGF) and leaf area index (LAI) have been tested under Western forest conditions. Keane et al. (2005) described and tested six indirect ground-based methods to measure CGF (AccuPAR ceptometer, CID digital plant canopy imager, hemispherical photography, LI-COR LAI-2000, point sampling, and spherical densiometer). Of these methods, the LAI-2000 instrument (LI-COR Biosciences Inc., Lincoln, NE, USA) measures transmittance of diffuse sky radiation through a vegetation canopy via separate optical sensors oriented at five zenith angles $(7,23$, 38,58 , and $\left.68^{\circ}\right)$. With this instrument, CGF and LAI are modeled in three dimensions using radiation attenuation rates at the different zenith angles (Norman and Welles 1983; Perry et al. 1988). In the Keane et al. (2005) study, iterative, incremental, destructive sampling of the 
coniferous forest canopy (25\% basal area removal per iteration) was performed to produce field estimates of CBD across a gradient of crown biomass conditions. Concurrently, they collected six intervening measurements of CGF (listed above) before and after each destructive removal of the forest basal area. Results were used to build a suite of regression models to relate CGF estimates to their direct field measurements of burnable CBD. One of their models (CID digital plant canopy imager; $R^{2}=0.94$, root mean squared error [RMSE] = $0.01 \mathrm{~kg} \mathrm{~m}^{-3}$ ) required the use of a tree height parameter, while the remaining models did not. Of the remaining methods tested, the summed weighted average of LAI2000 sensor data using the top three zenith angles ( 7 , 23 , and $38^{\circ}$ ) showed the strongest relationship to the maximum burnable CBD (foliage and small branches $<3$ $\mathrm{mm}$ diameter) in the vertical profile for Western coniferous forests $\left(R^{2}=0.70\right.$, RMSE $\left.=0.03 \mathrm{~kg} \mathrm{~m}^{-3}\right)$. Equation 1 shows the Keane et al. (2005) weighted transformation of CGF for estimating maximum burnable CBD (CBD, $\mathrm{kg} \mathrm{m}^{-3}$ ) across LAI-2000 zenith angles $\Theta_{i}$ :

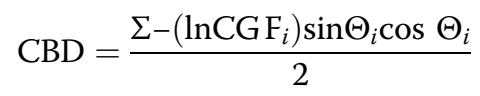

Field estimates of CBD may also be modeled using specific desktop software, such as FuelCalc (Reinhardt et al. 2006). Current versions of FuelCalc (e.g., v1.6, released February 2019) use lists of inventoried tree species, with the associated bole diameter at $1.37 \mathrm{~m}$ height and canopy position information, to model available canopy fuel (i.e., foliage plus half the fine branch material $\leq 6.3 \mathrm{~mm}$ diameter) using Brown's (1978) allometric biomass equations. In instances for which species-specific allometry for fine, burnable branch material is not available, less specific allometry is substituted. The resulting estimates of crown biomass are then scaled to fit Brown's (1978) equations (Reinhardt et al. 2006). In other cases, where no published allometry exists for a tree species, allometry for similar, substitute species is used. In such cases, canopy fuel estimates are adjusted using specific factors to account for crown position (Gray and Reinhardt 2003). It is important to note that the FuelCalc routine excludes all trees less than $1.83 \mathrm{~m}$ $(6 \mathrm{ft}$.) in height from CBD calculations, as biomass below this threshold is not canopy fuel, but rather surface fuel (Saatchi et al. 2007). As such, a substantial quantity of burnable, coniferous fuel in the Superior National Forest (SNF) in northern Minnesota, USA (Fig. 1), straddles this categorical boundary, especially balsam fir (Abies balsamea [L.] Mill.) (Frelich and Reich 1995).

In 2015, the US Forest Service funded a pilot study (see Engelstad et al. 2019) to investigate the potential improvement in methodologies for local modeling and mapping of forest structural parameters critical for modeling wildfire behavior within the Gunflint Ranger District of the SNF in northern Minnesota, USA (Fig. 1). Study-specific field data were combined with lowdensity lidar data $\left(0.44\right.$ points $\left.\mathrm{m}^{-2}\right)$ to model stand age, crown fuel height, live crown base height, and CBD. For CBD, field estimates were derived using three methods: US Forest Service plot-based line-intercept method (USDI National Park Service 2003), allometric modeling of component fuel biomass from biophysical tree data according to Perala and Alban (1994), and transformation of indirect measures of CGF according to Keane et al. (2005). Of the fuel variables modeled using randomForest (Breiman 2001) k-nearest neighbor imputation, CBD models were the weakest (adjusted coefficient of determination [Adj $R^{2}$ ] range $=0.32$ to 0.48; Engelstad et al. 2019) and did not exceed the accuracy of CBD estimates provided by the LANDFIRE program $\left(R^{2}=0.58\right)$ for the Lake States region, Zone 41 (LANDFIRE 2011). The low reported accuracy among modeled estimates of CBD is discouraging, especially since low-density lidar has been used successfully $\left(R^{2}>\right.$ 0.83 ) for these purposes in other regions (Andersen et al. 2005; Erdody and Moskal 2010). Thus, a need exists for alternative methodologies for mapping CBD within the SNF.

For passive satellite sensors (e.g., Landsat), the approximate 2-m boundary above ground level (AGL) separating canopy fuel from coniferous surface fuel is problematic for detection efforts, as such sensors are ill equipped to directly distinguish differences in fuel height (Keane et al. 2006; Saatchi et al. 2007; Jakubowksi et al. 2013). Data from active sensors (i.e., lidar and radar) represent a potential remedy for such limitations (see Keane et al. 2001; Keane et al. 2005). However, considering the marginal lidar-based CBD mapping results reported by Engelstad et al. (2019), coupled with decadelong revisit times proposed for higher-density lidar coverage (MNGAC [Minnesota Geospatial Advisory Council] 2020), an examination of the capabilities of synthetic aperture radar (SAR) satellite sensor data for quantifying $\mathrm{CBD}$ within this region is warranted due to proven canopy penetration characteristics (Huang et al. 2018). Encouraging CBD mapping results have been achieved $\left(R^{2}=0.85\right.$, RMSE $\left.=0.67 \mathrm{~kg} \mathrm{~m}^{-3}\right)$ using highresolution (i.e., 5 to $10 \mathrm{~m}$, L-band and P-band), polarimetric AIRSAR sensor data within Yellowstone National Park, USA (Saatchi et al. 2007). While the authors used allometric equations (Brown 1978; Van Hooser 1983) to derive field estimates of CBD from inventoried tree data, it is was unclear whether their estimates were equivalent to burnable CBD defined by Keane et al. (2005). In any event, it has yet to be determined whether data from space-based SAR sensors (e.g., Sentinel-1 and Palsar-1) 


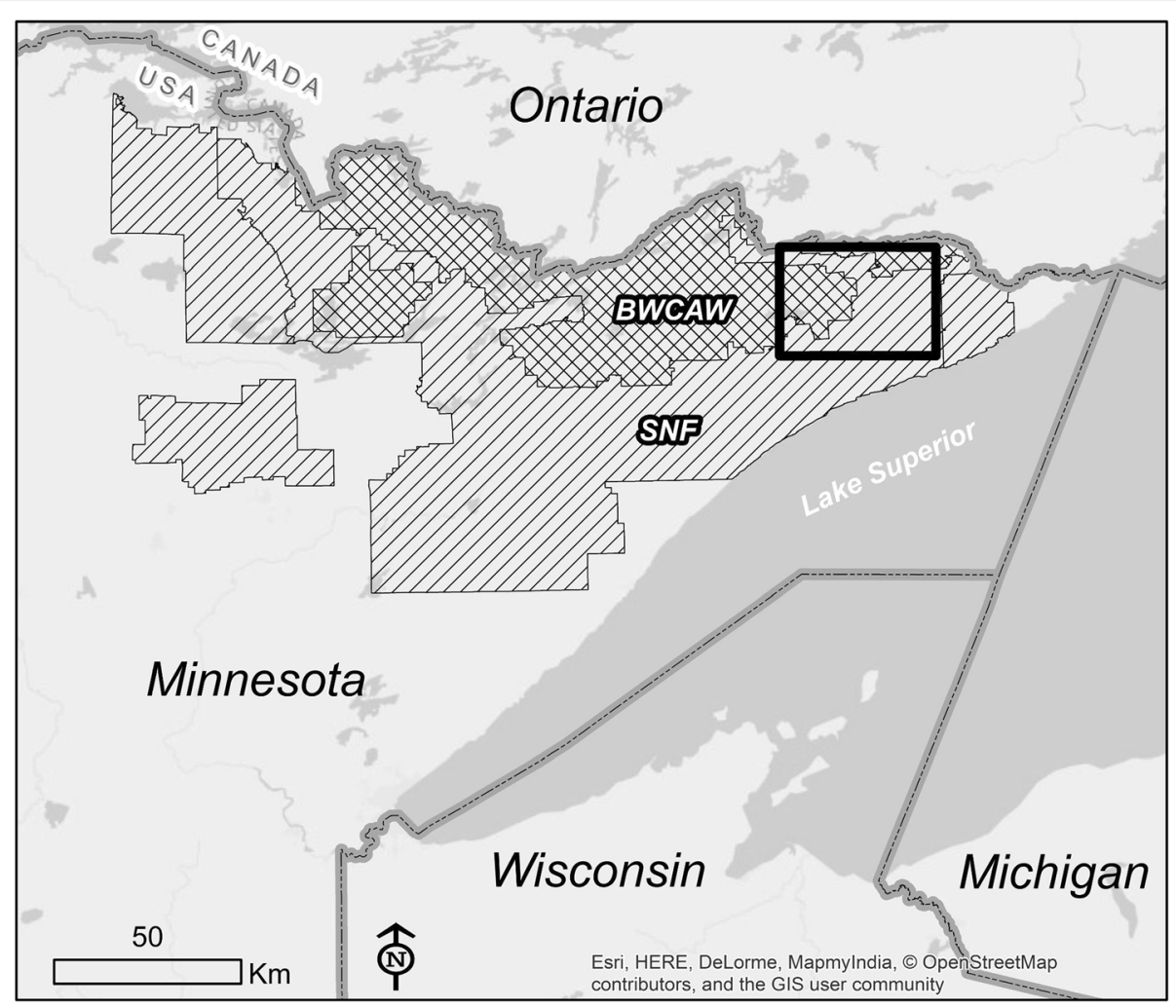

Fig. 1 Location of Minnesota, USA, pilot study area (black box) proximal to the Superior National Forest (SNF) and the Boundary Waters Canoe Area Wilderness (BWCAW) and Lake Superior. Here, we investigated the potential of mapping coniferous forest fuel density using satellite sensor data and ground data collected between 2015 and 2016

can afford similar CBD modeling results under Minnesota forest conditions. Moreover, it is important to determine whether the presence of coniferous surface fuel may influence CBD characterization, especially given the factors that affect canopy penetration depth (Ustin 2004; Schlund et al. 2019).

Hence, we combined study-specific biophysical field data with both SAR and optical satellite sensor data to calibrate models for estimation and mapping of CBD to support fire behavior modeling efforts in the SNF. Field estimation of CBD response variables included both (1) FuelCalc output and (2) weighted transformation of indirect optical field measurements of canopy gap fraction (CGF) according to Keane et al. (2005) using a LAI$2200 \mathrm{C}$ instrument (LI-COR Biosciences Inc.). The fusion of optical and SAR satellite sensor data has been shown to augment remote characterization of forest structure in this region (Wolter and Townsend 2011). As such, we hypothesized that inclusion of SAR backscatter amplitude imagery with optical satellite sensor data would enable increased characterization of forest CBD over that possible via low-density lidar in this region (Engelstad et al. 2019). We also investigated the potential effects of coniferous surface fuel density on our ability to distinguish and model CBD using SAR satellite sensor data, given the greater canopy penetration afforded by radar. Finally, we compared and discussed the results of CBD model calibration strategies and provided recommendations for their operational use.

\section{Methods}

Study area

The $356-\mathrm{km}^{2}$ pilot study area falls within the Gunflint Ranger District of the Superior National Forest (SNF), Minnesota, USA, and is a mix of both managed and wilderness forest (Fig. 1). Forest cover is diverse (e.g., five conifer genera and seven broadleaf genera) and is considered transitional between the sub-boreal Great Lakes-St. Lawrence forests and boreal forest (Heinselman 1973; Baker 1989). Non-wilderness forest areas are intensively managed for wood fiber, which has resulted in a dominance of quaking aspen (Populus tremuloides Michx.), paper birch (Betula papyrifera Marsh), white spruce (Picea glauca [Moench] Voss), and balsam fir forest associations (Frelich and Reich 1995; Wolter and White 2002). Wilderness areas have an extensive fire history that supports vast stands of pioneer forest dominated by jack pine (Pinus banksiana Lamb.), as well as remnants of old-growth white pine and red pine (Pinus strobus L. and P. resinosa Ait., respectively) (Heinselman 
1973; Frelich and Reich 1995). However, early twentieth century fire suppression policies led to an increase in the dominance of shade-tolerant, fire-sensitive balsam fir on this landscape (Frelich and Reich 1995; Corace et al. 2012). Several wilderness and non-wilderness areas within the northwestern portion of the study perimeter experienced the effects of a severe downburst wind event in 1999 that caused substantial wind throw damage (Rich et al. 2007). Much of the downed course woody material from this wind event persists today amidst the regenerating forest. Throughout much of the study area, balsam fir exists largely in the understory below dominant and co-dominant canopy associates (Frelich and Reich 1995; Wolter and Townsend 2011). High flammability and understory canopy position make balsam fir an effective ladder fuel for crown fire propagation (Abbas et al. 2011). Other conifer species in this study area include eastern larch (Larix laricina [Du Roi] K. Koch), northern white cedar (Thuja occidentalis L.), and black spruce (Picea mariana Mill.). The coniferous forest species within this landscape are the focus of this research, which we discuss in the methods below.

\section{Field sampling}

Personnel from the Gunflint Ranger District of the SNF generated and field-marked 110 random plot locations throughout the pilot study area (Fig. 1) as candidates for field sampling. We visited plots $(n=61)$ that were within
$1 \mathrm{~km}$ of a road (Fig. 2) in 2015 and 2016 to collect biophysical tree data and conifer CGF data, each needed to calibrate models for estimating burnable fuel biomass (primarily standing conifer foliage and twigs 0 to $3 \mathrm{~mm}$ in diameter) using two different approaches, described below. Approximately 20\% of these 61 randomly marked plot center locations fell in large canopy openings or on the boundary of such an opening. In such cases, we shifted plot centers toward adjacent intact forest by $\sim 42$ $\mathrm{m}$ (i.e., 30-m pixel diagonal dimension) to accommodate potential pixel registration errors and the spatial breadth of our field sampling design (Fig. 3). All plot locations were recorded using a dual-frequency Trimble Geo7X (H-Star) GPS receiver (Trimble Inc., Sunnyvale, CA, USA) and later differentially corrected (carrier-phase, mean 2dRMS $=0.48 \mathrm{~m}$ ) using the Grand Marais, Minnesota, CORS base station (https://www.ngs.noaa.gov/ CORS_Map/; site ID: GDMA).

The presence of broadleaf tree foliage during the growing season is problematic for forest fuel mapping using satellite sensor data and equally problematic for estimating conifer CGF. Broadleaf foliage partially conceals coniferous fuels from above while also causing erroneously high estimates of CGF from below canopy. In both cases, ground-to-space fuel density calibrations would be confounded. Therefore, we collected field CGF data during dormant, leaf-off conditions for broadleaved tree species (late October 2015 and early May 2016) to

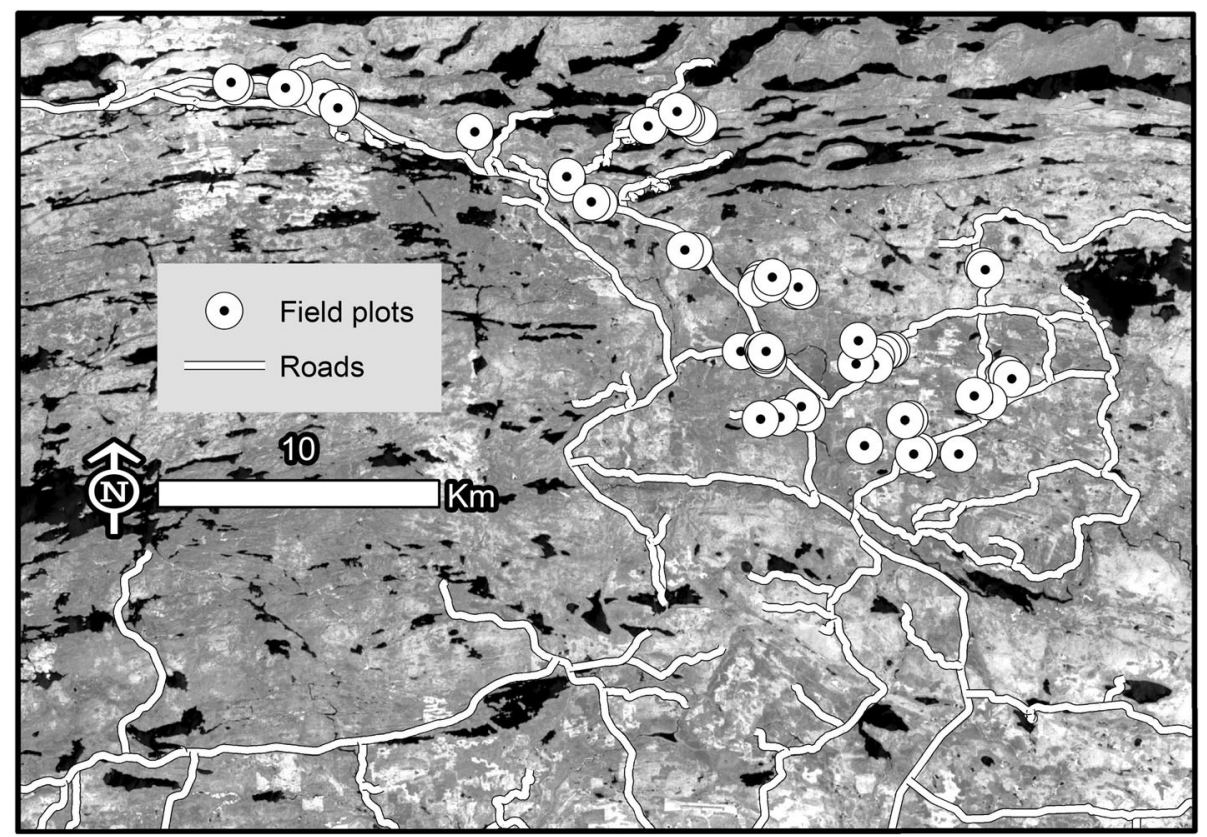

Fig. 2 Pilot study area showing 61 field plot locations within the Gunflint Ranger District of the Superior National Forest, Minnesota, USA. Field data collections occurred in 2015 and 2016 to investigate the potential of mapping coniferous forest fuel density using satellite sensor data and ground data. Plot locations and roads displayed on pre-leaf flush 7 May 2017 Sentinel-2 near-infrared imagery, in which lakes are black, conifer forest is dark gray, leaf-off broadleaf forest is bright gray, and mixed conifer-broadleaf forest is intermediate gray 


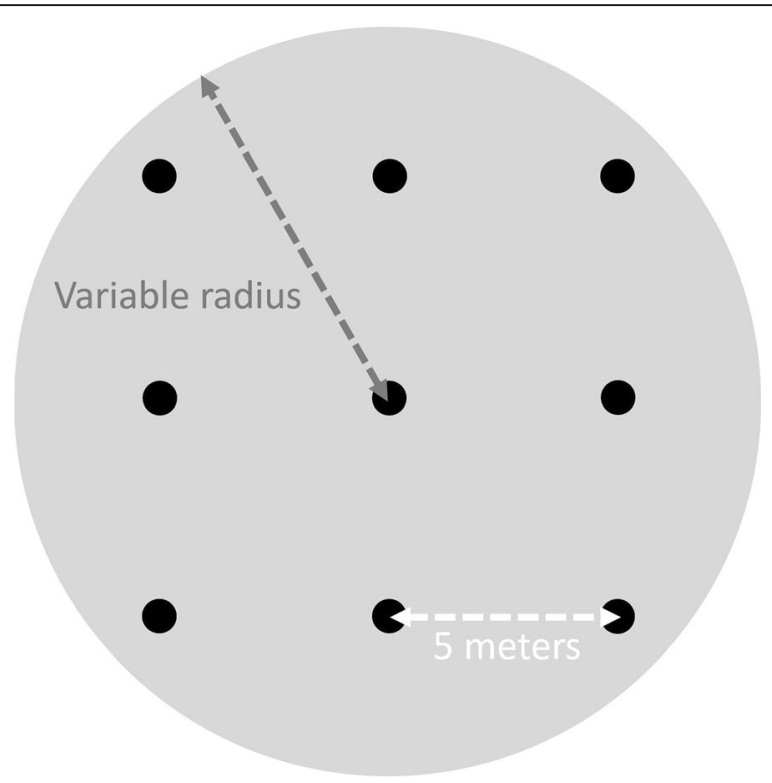

Fig. 3 Ground plot sampling design (2015 to 2016) to quantify coniferous forest fuel density for calibration with satellite sensor to enable mapping across the Superior National Forest, Minnesota, USA. Nine-point grid (black dots) at 5-m spacing are the canopy gap fraction (CGF) sample locations used to estimate coniferous fuel density. The central gray-shaded circle is a forest height-dependent fixed-radius plot (average area $=102 \mathrm{~m}^{2}$; standard deviation $=56.8$ $\mathrm{m}^{2}$ ) for measurement of tree biophysical dimensions (species, bole diameter, crown spread, and height to first live branch). Field data are used to calculate both canopy bulk density $\left(\mathrm{kg} \mathrm{m}^{-3}\right)$ via the FuelCalc routine and to estimate understory ( $\leq 3 \mathrm{~m}$ above ground) coniferous biomass ( $\mathrm{kg} \mathrm{m}^{-2}$ of ground area)

maximize the visibility of conifer foliage and branch structures from below the forest canopy. Similarly, dormant seasons are optimal for space-based visibility of these same coniferous fuel structures (Wolter et al. 2008). At each plot, we collected two types of ground data: CGF and tree species biophysical data (i.e., bole diameter at $1.37 \mathrm{~m}$ height, or $10 \mathrm{~cm}$ if height $\leq 1.37 \mathrm{~m}$; tree height; height to first live branch; and canopy diameter). On the rare occasion that trees were exactly $10 \mathrm{~cm}$ tall, we used the base diameter instead. We measured field CGF using a dual-sensor LI-COR LAI-2200C instrument (LI-COR Biosciences Inc.) during dawn and dusk hours to avoid direct sunlight. We placed one of the two LAI-2200C sensor wands at a fixed position in an open area (less than $100 \mathrm{~m}$ from a given forest plot) with an unobstructed view of sky conditions to collect measurements every $5 \mathrm{~s}$. Concurrently, the other wand was used below the forest canopy to collect CGF measurements at each of nine grid locations per plot $(3 \times 3$ at 5-m spacing), where the center grid location was the plot center (Fig. 3). Hence, all below-canopy measurements were time-synchronized (within $2.5 \mathrm{~s}$ ) to the open sky sensor. The grid was oriented north and south on flat terrain, or up and down slope, according to Keane et al. (2005). We recorded CGF for all nine grid locations at both ground level and at $2 \mathrm{~m}$ above ground level (AGL). Ground-level CGF measurements capture all fuel (i.e., surface and canopy fuels) within the LAI-2200C sensor's upward field of view, while 2-m AGL measurements capture just canopy fuel. In each instance, we used the top three zenith angles of the LAI-2200C sensor: $7^{\circ}(1), 23^{\circ}(2)$, and $38^{\circ}(3)$. Time-synchronized CGF digital readings from the open area and nine grid points were stored onboard their respective wands and later downloaded to a computer for post-processing to both eliminate spurious readings (transmittance $>1$ for each zenith angle) and to correct sub-canopy readings for varying open sky conditions. Resulting sets of skycorrected measurements were averaged by plot at each separate level $(0 \mathrm{~m}$ and $2 \mathrm{~m}$ AGL) and zenith angle range ( 0 to $7^{\circ}[1], 0$ to $23^{\circ}$ [12], and 0 to $38^{\circ}$ [123]) to provide more robust spatial estimates of CGF (LI-COR 2011).

We collected biophysical tree data for all trees (conifer and broadleaf) greater than $10 \mathrm{~cm}$ tall (4584 trees across 61 plots) within a single circular subplot concentric with the plot center (Fig. 3). The radius of each circular subplot varied by plot according to the product of the sine of the second LAI-2200C sensor zenith angle $\left(23^{\circ}\right)$ and the maximum tree height identified for each plot (Fig. 3 ). The resulting average ground plot circular area was $102 \mathrm{~m}^{2}$ with a standard deviation of $56.8 \mathrm{~m}^{2}$. We measured tree heights using a Trimble Laser Ace 1000 rangefinder (Trimble Inc.) to within circa $\pm 20 \mathrm{~cm}$ precision (Jamali et al. 2014). We collected crown spread measurements for trees taller than $5 \mathrm{~m}$ using a densitometer instrument, according to Wolter et al. (2009), and recorded bole diameters by species to estimate basal area $\left(\mathrm{m}^{2} \mathrm{ha}^{-1}\right)$. Conifer field data were used in two ways: (1) as FuelCalc inputs for determination of plot-wise maximum burnable CBD and (2) as means to estimate total bole, branch, and foliar biomass according to Perala and Alban (1994) to explore relationships between overstory canopy composition (i.e., broadleaf, mixed coniferbroadleaf, and percent canopy cover) and coniferous surface and lower canopy biomass ( $\leq 3 \mathrm{~m}$ AGL). For the latter analyses, tree-wise biomass values were stratified using respective live canopy cone volumes to distribute biomass vertically into 1-m increments (see Engelstad et al. 2019), which we summed by increment and normalized by ground plot area.

\section{Field estimates of coniferous fuel density}

We converted indirect LAI-2200C CGF data from each field plot to maximum, burnable fuel density $\left(\mathrm{kg} \mathrm{m}^{-3}\right)$ using the Keane et al. (2005) transformation equation (Eq. 1). Fuel density estimates included CBD (fuel $\geq 2 \mathrm{~m}$ 
AGL) and total fuel density (TFD; fuel $\geq 0 \mathrm{~m} \mathrm{AGL}$ ), which is primarily the sum of live, coniferous surface fuel density (SFD; 0 to $2 \mathrm{~m}$ AGL) plus CBD. We generated estimates of TFD and CBD across three LAI-2200C zenith angle range combinations: $\mathrm{TFD}_{1}, \mathrm{TFD}_{12}, \mathrm{TFD}_{123}$, $\mathrm{CBD}_{1}, \mathrm{CBD}_{12}$, and $\mathrm{CBD}_{123}$. Respective fuel density differences, TFD minus CBD, served as indirect field estimates of burnable SFD. It is important to note that transformation of CGF to fuel density $\left(\mathrm{kg} \mathrm{m}^{-3}\right)$, whether CBD, TFD, or SDF, includes all fuels visible to the LAI$2200 \mathrm{C}$ sensor, which consisted primarily of live coniferous fuel structures.

Field estimates of CBD were also determined allometrically using plot-wise biophysical tree data and the FuelCalc routine $\left(\mathrm{CBD}_{\mathrm{FC}} ; \mathrm{kg} \mathrm{m}^{-3}\right)$. As mentioned above, in the absence of species-specific allometry, FuelCalc makes use of allometry from structurally similar forest species to determine a plot's CBD profile (Lutes 2020), from which we extracted the maximum CBD. In northern Minnesota, most of the conifer species found in the pilot study area lacked the necessary allometry to calculate CBD. Hence, FuelCalc substituted the following species: Abies lasiocarpa (Hook.) Nutt. for Abies balsamea, Pinus contorta (Dougl.) for Pinus banksiana, Pinus ponderosa (Dougl.) for Pinus resinosa, Picea engelmannii (Parry) for Picea glauca, and Pseudotsuga menziesii (Mirb.) Franco for Picea mariana.

\section{Satellite sensor data}

Optical imagery. We acquired images from three optical satellite sensors (Table 1) for this study: five Landsat- 8 Operational Land Imager (OLI) scenes, one SPOT-5 multispectral (XS) image, and one Sentinel-2 Multispectral Instrument (MSI) image. All OLI images were from the worldwide reference system (WRS-2) path 26 row 27 footprint and were downloaded from the US Geological Survey's Earth Explorer portal (www.earthexplorer.org). Images came processed to surface reflectance, orthorectified, and geo-corrected as part of the Landsat Ecosystem Disturbance Adaptive Processing System (LEDAPS; Vermote et al. 1997; Masek et al. 2006). A SPOT-5 winter image (with $53-\mathrm{cm}$ snow ground cover) from 13 March 2013 was downloaded from the Earth Explorer portal (https://earthexplorer.usgs.gov/) under a temporary data purchase agreement between the US Geological Survey and SPOT Image Corporation (https:// www.spotimage.com/). Finally, a MSI image from 7 May 2017 (pre-leaf flush) was downloaded from the Earth Explorer portal (https://earthexplorer.usgs.gov/) as an orthometrically and radiometrically corrected top of atmosphere reflectance product. The relative humidity recorded by the Seagull remote automated weather station $\left(48.120536^{\circ},-90.838725^{\circ}\right)$ at the time of MSI image acquisition (1030 Central Daylight Time) was 40\%. Hence, further corrections to surface reflectance were not necessary, as our goals did not include date-specific change detection (see Song et al. 2001).

Landsat-8 OLI images for CBD, TFD, and SFD work included three leaf-off winter dates with snow ground cover (4 March 2014, 121-cm snow depth; 1 December 2015, 42-cm snow depth; and 19 February 2015, 53-cm snow depth), for which the Minnesota State Climatology Office provided date-specific estimates of snow depth (https://climateapps.dnr.state.mn.us/doc/snowmap.htm).

Table 1 Synthetic aperture radar (SAR) and optical satellite sensor characteristics and image dates used in this Minnesota, USA, study to quantify coniferous forest fuels using field data collected in 2015 and 2016. Images used to classify overstory canopy composition are in boldface. Sensors include the Phased Array L-band Synthetic Aperture Radar (PALSAR-1) aboard the Japan Aerospace Exploration Agency's Advanced Land Observing Satellite (ALOS); the European Space Agency's Sentinel-1 C-band SAR sensor (interferometric wide swath mode; IW) and their Sentinel-2 MultiSpectral Instrument (MSI) optical sensor; the Space Agency of France's fifth Satellite Pour I'Observation de la Terre (SPOT-5) multispectral (XS) optical sensor; and the US Geological Survey's optical Operational Land Imager (OLI) sensor aboard the Landsat-8 satellite. Polarization for SAR sensors includes horizontal send and receive $(\mathrm{HH})$, vertical send and receive $(\mathrm{W})$, and two cross-polarizations ( $\mathrm{HV}$ and $\mathrm{VH})$. Dashes $(-)$ denote multiple images from the same sensor

\begin{tabular}{|c|c|c|c|c|c|c|}
\hline Satellite & Sensor & Bands & Wavelength & Polarization & Pixel size $(m)$ & Date \\
\hline \multirow[t]{2}{*}{ ALOS } & Palsar-1 & 2 & $23.6 \mathrm{~cm}$ (L-band) & $\mathrm{HH}, \mathrm{HV}$ & 12 & 6 Nov 2010 \\
\hline & & & & & & 22 Dec 2010 \\
\hline \multirow[t]{3}{*}{ Sentinel-1 } & IW & 2 & $5.54 \mathrm{~cm}$ (C-band) & $\mathrm{W}, \mathrm{VH}$ & 10 & 18 May 2016 \\
\hline & & & & & & 4 Mar 2014 \\
\hline & & & & & & 8 Jun 2014 \\
\hline \multirow[t]{3}{*}{ Landsat-8 } & OLI & 6 & 435 to $2294 \mathrm{~nm}$ & - & 30 & 14 Oct 2014 \\
\hline & & & & & & 19 Feb 2015 \\
\hline & & & & & & 1 Dec 2015 \\
\hline Sentinel-2 & MSI & 6 & 444 to $2190 \mathrm{~nm}$ & - & 10,20 & 7 May 2017 \\
\hline SPOT-5 & XS & 4 & 500 to $1750 \mathrm{~nm}$ & - & 10,20 & 13 Mar 2013 \\
\hline
\end{tabular}


No precipitation events were recorded for at least 2 weeks prior to each winter image date. Two leaf-on Landsat- 8 images (8 June and 14 October 2014) were acquired for the determination of overstory canopy composition. The 14 October imagery coincided with peak foliar senescence (autumn leaf coloration) of quaking aspen and paper birch, which served to augment multispectral contrast with other forest species in the overstory (Wolter et al. 1995). The 8 June OLI image served as a growing-season contrast to October OLI sensor data. Optical remote sensing data from dormant seasons are optimal for observing conifer canopies otherwise obscured by broadleaf tree foliage (Sayn-Wittgenstein 1961; Wolter et al. 2008). Moreover, winter optical imagery capturing snow ground cover conditions is ideal because potential spectral confusion between canopy and forest floor is minimized (Wolter et al. 2012).

In addition to optical sensor bands from each date, we calculated three indices for use as predictors of burnable fuel density: normalized difference vegetation index (NDVI; Rouse et al. 1974), shortwave infrared to nearinfrared ratio (SWIR:NIR; Vogelmann and Rock 1988), and SWIR to visible ratio (SVR; Wolter et al. 2008) (Table 2). We also included ten mapped estimates of forest basal area (total, conifer, broadleaf, and seven conifer species; Wolter and Townsend 2011) at 30-m spatial resolution to the pool of optical predictors. Thus, there were 61 initial optical sensor predictors and ten structure estimates as predictors available for calibrations with ground data.

Synthetic aperture radar imagery. We acquired SAR backscatter amplitude imagery (Table 1) from two satellite sensors (Sentinel-1 and Palsar-1) to complement optical sensor data for calibrating fuel density models (TFD, SFD, and CBD). We downloaded Sentinel-1 dualpolarity (vertical send, vertical receive [VV]; vertical send, horizontal receive $[\mathrm{VH}]$ ) C-band SAR interferometric wide (IW) imagery from 16 May 2016 from the European Space Agency's Copernicus Open Access Hub website (https://scihub.copernicus.eu/dhus/\#/home) as ground range detected images georeferenced and resampled to a common pixel spacing $(10 \mathrm{~m})$ in both range and azimuth. These SAR data captured pre-leaf flush conditions for deciduous tree species in the study area. Leaf-off Palsar-1 dual-polarization (HH, HV) Lband data from 6 November 2010 (no snow cover) and 22 December 2010 (38-cm snow cover) were downloaded from the Alaska Satellite Facility's NASA distributed active archive center as high-resolution $(12.5 \mathrm{~m})$, terrain-corrected backscatter amplitude imagery (https:// www.asf.alaska.edu/about/asf-daac/).

In addition to the original six SAR bands (Table 1), we calculated three ratios to highlight potential differences in canopy volume structures (Joshi et al. 2017). Ratios included May Sentinel-1 send-receive polarization ratio (VH:VV) and two Sentinel-1 to Palsar-1 cross-frequency, cross-polarization ratios $\left(\mathrm{VH}_{\mathrm{C}}: \mathrm{HV}_{\mathrm{L}}\right.$ and $\mathrm{VV}_{\mathrm{C}}: \mathrm{HH}_{\mathrm{L}}$, referred hereafter without frequency subscripts $\mathrm{C}$ and $\mathrm{L}$ ). We created 24 additional SAR predictors from a subset of the original bands and ratio images described above using $3 \times 3,5 \times 5$, and $7 \times 7$ low-pass filters to spatially dampen high-frequency, signal-dependent noise (Sader 1987; Rauste 2005). Thus, there were 31 SAR variables available for fuel density calibration procedures, along with a subset of 25 optical sensor predictors from leafoff seasons (Table 1).

Table 2 Landsat-8 Operational Land Imager (OLI), SPOT-5 multispectral (XS), and Sentinel-2 Multispectral Instrument (MSI) bands; wavelength intervals $(\lambda)$; and indices used as predictors of forest structural attributes in this Minnesota, USA, study to quantify coniferous forest fuel using field data collected in 2015 and 2016. Indices include normalized difference vegetation index (NDVl; Rouse et al. 1974), shortwave infrared to near-infrared ratio (SWIR:NIR; Vogelmann and Rock 1988), and SWIR to visible ratio (SVR; Wolter et al. 2008). Equations for NDVI, SWIR:NIR, and SVR are shown using sensor-specific band numbers defined below each sensor column. Dashes (-) denote where SPOT-5 lacks an equivalent predictor band

\begin{tabular}{|c|c|c|c|c|c|c|}
\hline \multirow[t]{2}{*}{ Predictor } & \multicolumn{2}{|c|}{ Landsat-8 OLI } & \multicolumn{2}{|c|}{ SPOT-5 XS } & \multicolumn{2}{|c|}{ Sentinel-2 MSI } \\
\hline & Band & $\lambda(\mathrm{nm})$ & Band & $\lambda(\mathrm{nm})$ & Band & $\lambda(\mathrm{nm})$ \\
\hline Blue & 2 & 452 to512 & - & - & 2 & 458 to 523 \\
\hline Green & 3 & 533 to 590 & 1 & 500 to 590 & 3 & 543 to 578 \\
\hline Red & 4 & 636 to 673 & 2 & 610 to 680 & 4 & 650 to 680 \\
\hline Near-IR & 5 & 851 to 879 & 3 & 780 to 890 & 8 & 785 to 899 \\
\hline SWIR1 & 6 & 1566 to 1651 & 4 & 1580 to 1750 & 11 & 1565 to 1655 \\
\hline \multirow[t]{2}{*}{ SWIR2 } & 7 & 2107 to 2294 & - & - & 12 & 2100 to 2280 \\
\hline & \multicolumn{2}{|c|}{ Equation } & \multicolumn{2}{|c|}{ Equation } & \multicolumn{2}{|c|}{ Equation } \\
\hline NDVI & \multicolumn{2}{|c|}{$(5-4) \div(5+4)$} & \multicolumn{2}{|c|}{$(3-2) \div(3+2)$} & \multicolumn{2}{|c|}{$(8-4) \div(8+4)$} \\
\hline SWIR:NIR & \multicolumn{2}{|l|}{$6 \div 5$} & \multicolumn{2}{|l|}{$4 \div 3$} & \multicolumn{2}{|c|}{$11 \div 8$} \\
\hline SVR & \multicolumn{2}{|c|}{$(6+7) \div(2+3+4)$} & \multicolumn{2}{|c|}{$4 \div(1+2)$} & \multicolumn{2}{|c|}{$(11+12) \div(2+3+4)$} \\
\hline
\end{tabular}


Prior to ground-to-satellite calibration analyses and mapping, we identified and masked forest change areas due to harvest (i.e., clear-cutting, November 2010 to May 2017) from all image data.

\section{Ground-to-satellite model calibration}

Partial least squares regression. We performed model calibrations between ground data and satellite sensor data using iterative exclusion partial least squares regression (xPLS; Wolter et al. 2008, Wolter et al. 2012). The XPLS algorithm was originally adapted for use with the PLS regression routine in SAS (SAS Institute Inc., Cary, NC, USA; Wolter et al. 2008) and later modified to run in Matlab v. R2010a (Mathworks Inc., Natick, MA, USA; Wolter et al. 2012; Singh et al. 2013). The xPLS model-building routine iteratively withholds individual predictor variables and performs intermediate cross-validations (Gong 1986) to determine the optimal number of latent components to use. This is important because, as latent dimensionality increases, lower order latent components-often describing random measurement error-are more likely to retain collinearity issues (see Wolter et al. 2008 and Geladi and Kowalski 1986 for a detailed discussion of PLS regression and latent variable structure). The predictor variable that, when withheld, results in the greatest improvement in RMSE is permanently removed from further analysis. The model-building process proceeds iteratively until the search for improvements in model RMSE is exhausted, at which time prediction accuracy is assessed using the results of cross-validation, including predicted residual error sum of squared (PRESS) statistic (Geladi and Kowalski 1986) and Adj $R^{2}$.

Fuel density model calibration. Using the XPLS routine, respective field estimates of TFD and CBD were each analyzed independently against the candidate group of 77 optical and SAR image predictors to calibrate parsimonious models (fewest predictors) for estimating fuel density metrics (i.e., $\mathrm{TFD}_{1}, \mathrm{TFD}_{12}, \mathrm{TFD}_{123}, \mathrm{CBD}_{1}$, $\mathrm{CBD}_{12}, \mathrm{CBD}_{123}$, and $\mathrm{CBD}_{\mathrm{FC}}$ ). We also used the three respective differences between TFD and CBD to build models for surface fuel density $\left(\mathrm{SFD}_{1}, \mathrm{SFD}_{12}\right.$, and $\left.\mathrm{SFD}_{123}\right)$. Given the procedural differences in deriving fuel density estimates (i.e., CGF and FuelCalc), we chose to perform separate XPLS regression sequences for each response variable. In each instance, final model calibrations were assessed based on results of leave-one-out cross-validation (PRESS), Akaike's information criterion (AIC; Akaike 1973), Bayesian information criterion (BIC; Schwartz 1978), and other standard metrics (Adj $R^{2}$ and RMSE). Relationships between respective field estimates of fuel density were evaluated using Pearson correlation plots (Müller and Büttner 1994). For canopy fuels, we used each final set of image predictors for mapping the respective estimates of CBD across the SNF study area.

Understory conifer biomass and overstory forest structure We performed two sets of analyses to compare observed levels of live coniferous biomass present in the forest understory (e.g., boles, branches, and foliage $\leq 3$ m AGL) to factors known to affect forest understory light environment: (1) percent canopy cover and (2) Anderson (1976) level-II forest types (Zavitkovski 1976; Messier et al. 1998; Légaré et al. 2002). While LAI-2200C CGF data measured from the narrowest zenith angle $\left(7^{\circ}\right)$ are suitable for measuring forest canopy cover (Paletto and Tosi 2009), our CGF data were insufficient in this respect as they were intentionally collected during dormant seasons, when all broadleaf species were leafless, to optimize visibility of coniferous fuels. Hence, we downloaded the 2016 continuous tree canopy cover dataset from the Multi Resolution Land Characteristic (MRLC) Consortium website (https://www.mrlc.gov/data/type/ tree-canopy). Understory biomass was calculated using our biophysical tree data and local allometry (Perala and Alban 1994) and scaled to ground plot area, as FuelCalc excludes a substantial portion of this biomass, especially below 2 m AGL. Next, we classified overstory forest cover into two Anderson level-II types (broadleaf and mixed broadleaf-conifer) using 8 June 2014 and 14 October 2014 Landsat-8 OLI sensor data and unsupervised classification techniques, for which 2015 leaf-on color infrared aerial photography (https://www.dnr.state.mn. us/maps/landview/) served as ground truth.

Conifers were not present at nine plots, reducing sample size for understory biomass comparisons from 61 to 52. Of these 52 plots, we identified two potentially influential outliers based on results of a multiple regression procedure performed on overstory composition and canopy cover against understory coniferous biomass. Each of these plots had Cook's distance $(D)$ metric (Cook 1979) greater than four times the mean $D$, which is a conservative outlier threshold (see Kutner et al. 2005). In one instance, we noted that understory biomass was substantially higher than all other plots, while canopy cover from our MRLC source was $70 \%$. This was suspect since we only measured six trees greater than $6 \mathrm{~m}$ tall on that plot. On the other plot, understory biomass was also high, while field data did not show an inordinate number of trees with either heights or height to first live branch below $3 \mathrm{~m}$ AGL. Hence, we removed these plots from further analysis. We tested the remaining field data for mean contrast among two levels of vertical biomass ( 0 to $2 \mathrm{~m}$ AGL and 0 to $3 \mathrm{~m}$ AGL) using Tukey's honestly significant difference test (HSD; Tukey 1953) across two separate overstory groups: forest type and canopy cover. Of the 50 field plots, there were 19 with broadleaf 
overstory and 31 with a mixed broadleaf-conifer overstory, while 13 plots had overstory canopy cover in the 47 to $66 \%$ range and 37 plots in the 67 to $78 \%$ range.

\section{Results}

Fuel density calibrations with satellite sensor data

We performed model calibrations between groundbased fuel density estimates (TFD, SFD, and CBD) and satellite sensor data in separate XPLS regression sequences (Tables 3 and 4). Among these, all xPLS regression attempts between CGF-based estimates of SFD and satellite image predictors failed to resolve viable solutions and were aborted. For TFD and CBD, all ground-to-satellite calibrations yielded strong models based on statistical metrics except $\mathrm{TFD}_{1}$ (Table 5). Of these, the four CBD models performed similarly (Adj $R^{2}=0.95$ to 0.98 , RMSE $=0.05$ to 0.17 $\mathrm{kg} \mathrm{m}^{-3}$, and PRESS < 0.47) and were superior to the TFD group of fuel models according to these metrics (Table 5, Fig. 4). The TFD group of models $\left(\mathrm{TFD}_{1}\right.$, $\mathrm{TFD}_{12}$, and $\mathrm{TFD}_{123}$ ) derived from weighted groundlevel CGF data were less complex in that they used fewer of the initial 66 satellite-based predictors (11, 16 , and 23 predictors used, respectively) with lower latent dimensionality (i.e., orthogonal components) with respect to the response variable (Table 5). However, all of the TFD models resulted in overprediction bias for low values of fuel density and the opposite trend among the upper range of fuel density compared to field estimates (Fig. 4).

Final reduced sets of image predictor variables retained from the initial set of 66 candidate predictors (31 SAR, 25 leaf-off optical, and 10 basal area estimates from Wolter and Townsend 2011) for the seven models varied from 11 for $\mathrm{TFD}_{1}$ to 38 for $\mathrm{CBD}_{123}$ (Tables 3 and 4). The two CGF-based sets of fuel models $\left(\mathrm{TFD}_{1-123}\right.$ and $\mathrm{CBD}_{1-123}$ ) revealed some trends in predictor variable retention. Only one of the TFD models (123) retained any of the OLI predictor variables (green band from 19 February 2015; OLI 3), while the CBD models collectively retained 13 of the OLI predictors. On average, each set of three CGF-based TFD and CBD models retained similar proportions of SAR predictors (48.8 and 43.7\%, respectively; Table 4). However, TFD models, on average, used a greater proportion of cross-frequency SAR ratio predictors $(18.0 \%$ versus $5.8 \%$; Table 4$)$, while the three CBD models retained a higher proportion of Lband predictors on average (15.1\% versus $4.5 \%)$. Overall, CGF-based CBD models collectively retained a more uniform mix of both SAR and optical variables (Table 3 ). No clear trends in predictor variable retention by zenith angle range emerged among the three LAI-2200C sensor zenith angle ranges $\left(0\right.$ to $7^{\circ}, 0$ to $23^{\circ}$, and 0 to $38^{\circ}$ ) used for TFD and CBD model development.
However, the $\mathrm{TFD}_{1}$ model was substantially different from the $\mathrm{CBD}_{1}$ model in this respect, retaining 0 versus $7 \mathrm{C}$-band and 1 versus $5 \mathrm{~L}$-band SAR predictors in favor of cross-frequency $\mathrm{SAR}$ ratios. The $\mathrm{CBD}_{\mathrm{FC}}$ model showed variable retention trends similar to that of the CGF-based CBD models (Tables 3 and 4).

Last, the TFD and CBD models retained different numbers of the basal area estimate variables from the Wolter and Townsend (2011) study (Table 3). The TFD models retained two to four of these basal area estimates, while CGF-based CBD models retained five to seven and $\mathrm{CBD}_{\mathrm{FC}}$ retained four. All seven of these fuel density models retained the white spruce basal area estimate predictor and, all four CBD models retained the red pine basal area estimate predictor. All but two of the fuel density models $\left(\mathrm{TFD}_{12}\right.$ and $\mathrm{CBD}_{1}$ ) retained the eastern white pine basal area predictor. There were no clear predictor retention trends among fuel density models by CGF measurement elevation or LAI-2200C zenith angle range (Table 3).

\section{Comparison of fuel density estimates and distributions}

To keep modeled fuel density results in perspective, the reader should note that plot-wise field estimates of $\mathrm{CBD}$ derived via FuelCalc $\left(\mathrm{CBD}_{\mathrm{FC}}\right)$ were treated here as quasiground truth (modeled, not actual), even though Western species substitutions were necessary (R. Keane, US Forest Service, Rocky Mountain Research Station, Missoula, MT, USA; personal communication). That said, correlations between our seven estimates of fuel density and the CBD estimates from LANDFIRE $\left(\mathrm{CBD}_{\mathrm{LF}}\right)$ are shown in Fig. 5 along with their respective data distributions. As expected, estimates of CBD and TFD derived from the weighted transformation of CGF according to Keane et al. (2005) were more strongly correlated among respective levels of CGF measurement than between them (Figs. 4 and 5). All six CGF-based estimates of fuel density show substantially weaker but significant correlation (Fig. 5) with FuelCalc-derived estimates of CBD (predicted $\mathrm{CBD}_{\mathrm{FC}}$ ), for which $\mathrm{TFD}_{12}$ and $\mathrm{TFD}_{123}$ showed the strongest correlations $(r=0.51, P=0.001)$. Correlations between $\mathrm{CBD}_{\mathrm{LF}}$ and CGF-based estimates of fuel density were either not significant or marginal $(r=0.25$ to $0.31, P=0.1$ to 0.05 ). The relationship between the $\mathrm{CBD}_{\mathrm{LF}}$ and $\mathrm{CBD}_{\mathrm{FC}}$ estimates was not significant (Fig. 5).

Measures of TFD and CBD distribution shape (skewness, SK; and kurtosis, KU) across our 61 ground plots vary among the different field fuel estimates (Figs. 5 and 6). According to Bulmer (1979), the $\mathrm{TFD}_{12}$, TFD $123, \mathrm{CBD}_{12}, \mathrm{CBD}_{123}$, and $\mathrm{CBD}_{\mathrm{LF}}$ estimates of fuel density have distributions that may be considered symmetric around the mean (i.e., SK between -0.5 and +0.5 ), while $\mathrm{TFD}_{1}$ and $\mathrm{CBD}_{1}$ show moderate, positive skew $(\mathrm{SK}=0.56$ to 0.59$)$. The 
Table 3 Final sets of image predictors (left side) and model coefficients for respective total fuel density (TFD; $\mathrm{kg} \mathrm{m}^{-3}$ ) and canopy bulk density models (CBD; $\mathrm{kg} \mathrm{m}^{-3}$ ) calibrated using dependent ground data collected in 2015 and 2016 in the Superior National Forest, Minnesota, USA. Model subscript notations 1, 12, and 123 reference the zenith angle range used for canopy gap fraction (CGF) measurements ( 0 to $7^{\circ}, 0$ to $23^{\circ}$, and 0 to $38^{\circ}$, respectively), while FC represents FuelCalc-derived field estimates of CBD. Dashes (-) indicate image predictors removed during model calibration. Image predictors include synthetic aperture radar (SAR) backscatter amplitudes and ratios, optical sensor bands and ratios, and previously derived estimates of forest basal area (BA) by species or group: Abies balsamea (ABBA), conifer (CON), broadleaf (BRD), Larix laricina (LALA), Picea glauca (PIGL), Picea mariana (PIMA), Pinus resinosa (PIRE), Pinus strobus (PIST), and total basal area (Total). Where necessary, image month is indicated. Combinations of SAR send and receive polarization are indicated with $\mathrm{H}$ (horizontal) and $\mathrm{V}$ (vertical). Spatially filtered (low-pass) versions of original resolution SAR variables have notations $3 \times 3,5 \times 5$, and $7 \times 7$. Optical sensor indices include the normalized difference vegetation index (NDVI), shortwave infrared to near-infrared ratio (SWIR:NIR), and SWIR to visible ratio (SVR). Sensors include Phased Array L-band Synthetic Aperture Radar (PALSAR-1); Sentinel-1 C-band SAR; Sentinel-2 optical MultiSpectral Instrument (MSI); Satellite Pour l'Observation de la Terre (SPOT-5) multispectral (XS) optical sensor; and Landsat-8's optical Operational Land Imager (OLI)

\begin{tabular}{|c|c|c|c|c|c|c|c|}
\hline & $\mathrm{TFD}_{1}$ & $\mathrm{TFD}_{12}$ & $\mathrm{TFD}_{123}$ & $\mathrm{CBD}_{1}$ & $\mathrm{CBD}_{12}$ & $\mathrm{CBD}_{123}$ & $\mathrm{CBD}_{\mathrm{FC}}$ \\
\hline \multicolumn{8}{|l|}{ Sentinel-2A (MSI) } \\
\hline MSI 2 & 0.0014 & 0.0104 & - & - & 0.0070 & 0.0085 & - \\
\hline MSI 3 & - & -0.0058 & -0.0083 & - & -0.0041 & - & - \\
\hline MSI 4 & - & - & - & -0.0019 & - & -0.0109 & -0.0044 \\
\hline MSI 8 & - & - & - & 0.0005 & -0.0021 & -0.0018 & - \\
\hline MSI 11 & 0.0000 & - & 0.0055 & - & - & - & - \\
\hline MSI 12 & 0.0000 & - & - & - & 0.0068 & 0.0118 & 0.0084 \\
\hline MSI NDVI & - & - & - & -0.0247 & 0.0585 & - & - \\
\hline MSI SVR & -0.0419 & - & -5.2946 & - & -3.1050 & -5.5613 & -7.2481 \\
\hline MSI SWIR:NIR & - & - & - & - & - & - & 2.9540 \\
\hline \multicolumn{8}{|l|}{ Palsar-1 (P1) } \\
\hline $\mathrm{HH}, 5 \times 5, \mathrm{Dec}$ & - & - & - & - & 17.7236 & 25.2843 & -12.0514 \\
\hline $\mathrm{HH}, 7 \times 7, \mathrm{Dec}$ & - & - & -12.5204 & -8.0620 & -33.3317 & -47.0995 & - \\
\hline $\mathrm{HH}, 3 \times 3, \mathrm{Nov}$ & - & - & - & -2.8668 & - & - & - \\
\hline $\mathrm{HH}, 5 \times 5, \mathrm{Nov}$ & -0.7608 & - & - & - & -12.8692 & -24.8212 & - \\
\hline $\mathrm{HH}, 7 \times 7, \mathrm{Nov}$ & - & - & - & 3.5551 & 14.6509 & 27.6294 & - \\
\hline $\mathrm{HV}, \mathrm{Nov}$ & - & - & - & -2.5963 & - & - & - \\
\hline $\mathrm{HV}, 5 \times 5, \mathrm{Nov}$ & - & - & - & - & - & -19.4630 & -48.3685 \\
\hline $\mathrm{HV}, 7 \times 7, \mathrm{Nov}$ & - & - & - & 11.7498 & 15.6451 & 44.7208 & 80.4010 \\
\hline \multicolumn{8}{|c|}{ Landsat-8 (OLI) Feb } \\
\hline OLI 2 & - & - & - & -0.0002 & - & - & - \\
\hline OLI 3 & - & - & 0.0002 & - & - & - & -0.0032 \\
\hline OLI 5 & - & - & - & -0.0001 & 0.0004 & 0.0013 & 0.0030 \\
\hline OLI 6 & - & - & - & 0.0010 & -0.0007 & -0.0023 & -0.0033 \\
\hline OLI NDVI & - & - & - & - & -0.0265 & -0.0223 & - \\
\hline OLI SVR & - & - & - & -5.9211 & 0.0121 & 0.0053 & -0.0314 \\
\hline OLI SWIR:NIR & - & - & - & - & - & 24.7883 & 50.4194 \\
\hline \multicolumn{8}{|l|}{ Sentinel-1 (S1) } \\
\hline $\mathrm{VH}$ & - & - & - & 0.0066 & 0.0141 & 0.0332 & 0.0259 \\
\hline $\mathrm{VH}, 3 \times 3$ & - & 0.0630 & 0.0625 & - & - & - & - \\
\hline $\mathrm{VH}, 5 \times 5$ & - & -0.1781 & -0.1152 & -0.0349 & -0.1061 & -0.2172 & -0.1708 \\
\hline$V H, 7 \times 7$ & - & 0.0642 & - & 0.0291 & 0.0645 & 0.0961 & - \\
\hline W & - & -0.0106 & -0.0251 & -0.0103 & -0.0061 & -0.0142 & -0.0095 \\
\hline$W, 3 \times 3$ & - & - & 0.0205 & 0.0147 & - & - & - \\
\hline
\end{tabular}


Table 3 Final sets of image predictors (left side) and model coefficients for respective total fuel density (TFD; $\mathrm{kg} \mathrm{m}^{-3}$ ) and canopy bulk density models (CBD; $\mathrm{kg} \mathrm{m}^{-3}$ ) calibrated using dependent ground data collected in 2015 and 2016 in the Superior National Forest, Minnesota, USA. Model subscript notations 1, 12, and 123 reference the zenith angle range used for canopy gap fraction (CGF) measurements ( 0 to $7^{\circ}, 0$ to $23^{\circ}$, and 0 to $38^{\circ}$, respectively), while FC represents FuelCalc-derived field estimates of CBD. Dashes (-) indicate image predictors removed during model calibration. Image predictors include synthetic aperture radar (SAR) backscatter amplitudes and ratios, optical sensor bands and ratios, and previously derived estimates of forest basal area (BA) by species or group: Abies balsamea (ABBA), conifer (CON), broadleaf (BRD), Larix laricina (LALA), Picea glauca (PIGL), Picea mariana (PIMA), Pinus resinosa (PIRE), Pinus strobus (PIST), and total basal area (Total). Where necessary, image month is indicated. Combinations of SAR send and receive polarization are indicated with $\mathrm{H}$ (horizontal) and $\mathrm{V}$ (vertical). Spatially filtered (low-pass) versions of original resolution SAR variables have notations $3 \times 3,5 \times 5$, and $7 \times 7$. Optical sensor indices include the normalized difference vegetation index (NDVI), shortwave infrared to near-infrared ratio (SWIR:NIR), and SWIR to visible ratio (SVR). Sensors include Phased Array L-band Synthetic Aperture Radar (PALSAR-1); Sentinel-1 C-band SAR; Sentinel-2 optical MultiSpectral Instrument (MSI); Satellite Pour l'Observation de la Terre (SPOT-5) multispectral (XS) optical sensor; and Landsat-8's optical Operational Land Imager (OLI) (Continued)

\begin{tabular}{|c|c|c|c|c|c|c|c|}
\hline & $\mathrm{TFD}_{1}$ & $\mathrm{TFD}_{12}$ & $\mathrm{TFD}_{123}$ & $\mathrm{CBD}_{1}$ & $\mathrm{CBD}_{12}$ & $\mathrm{CBD}_{123}$ & $\mathrm{CBD}_{\mathrm{FC}}$ \\
\hline$W, 5 \times 5$ & - & 0.0452 & - & - & 0.0488 & 0.1091 & 0.0981 \\
\hline$W, 7 \times 7$ & - & - & 0.0488 & - & -0.0182 & -0.0350 & - \\
\hline $\mathrm{VH}: \mathrm{W}$ & - & -0.0034 & -0.0030 & -0.0005 & - & -0.0013 & -0.0028 \\
\hline $\mathrm{VH}: \mathrm{W}, 5 \times 5$ & - & 0.0146 & - & 0.0027 & 0.0108 & 0.0278 & 0.0319 \\
\hline $\mathrm{VH}: \mathrm{W}, 7 \times 7$ & - & 0.0038 & 0.0185 & - & - & - & - \\
\hline \multicolumn{8}{|c|}{ S1:P1 (Nov) ratios } \\
\hline VH:HV & -0.0051 & - & - & - & - & - & -0.1553 \\
\hline $\mathrm{VH}: \mathrm{HV}, 3 \times 3$ & - & - & 0.3947 & - & - & - & - \\
\hline $\mathrm{VH}: \mathrm{HV}, 5 \times 5$ & -0.0051 & - & -0.4542 & -0.0950 & - & - & -0.1553 \\
\hline $\mathrm{VH}: \mathrm{HV}, 7 \times 7$ & -0.0025 & -0.0706 & - & 0.0770 & - & - & 0.4612 \\
\hline $\mathrm{W}: \mathrm{HH}, 5 \times 5$ & - & 1.2505 & - & -0.8196 & -1.6456 & -3.7624 & - \\
\hline $\mathrm{W}: \mathrm{HH}, 7 \times 7$ & - & 1.9131 & - & 0.9522 & 2.1599 & 4.6099 & - \\
\hline \multicolumn{8}{|l|}{ SPOT-5 (XS) } \\
\hline XS 1 & - & - & - & -0.0341 & -0.0851 & -0.1435 & - \\
\hline XS 2 & - & - & 0.1409 & 0.0368 & 0.0488 & 0.1022 & 0.1278 \\
\hline XS 3 & - & -0.0172 & -0.1854 & - & - & -0.0781 & - \\
\hline XS 4 & -0.0028 & - & - & -0.0201 & - & 0.0618 & -0.1030 \\
\hline XS NDVI & - & - & - & - & 0.0367 & 0.0770 & 0.0228 \\
\hline XS SVR & - & -1.2025 & - & -2.5112 & -10.5606 & -17.6685 & 4.6225 \\
\hline SWIR:NIR & - & - & - & 2.1590 & 6.5851 & 9.2176 & - \\
\hline \multicolumn{8}{|l|}{ BA estimates } \\
\hline ABBA & - & - & -0.6006 & - & 1.8371 & 2.3587 & - \\
\hline CON & - & - & 0.3828 & -0.1695 & -0.3521 & - & - \\
\hline $\mathrm{BRD}$ & - & - & - & - & -0.3770 & -0.5943 & - \\
\hline LALA & - & - & 2.8078 & 1.6604 & - & - & - \\
\hline PIGL & 0.4334 & 1.2487 & 1.6620 & 1.9919 & 2.2904 & 2.8725 & -2.5577 \\
\hline PIMA & - & - & -0.5171 & - & 0.2985 & - & - \\
\hline PIRE & - & - & - & 0.4379 & 1.2880 & 1.3795 & -0.9524 \\
\hline PIST & 1.3065 & - & 4.5840 & - & -2.8129 & -4.6389 & -1.1636 \\
\hline Total & - & 0.2282 & - & - & - & - & 1.7470 \\
\hline
\end{tabular}

$\mathrm{CBD}_{\mathrm{FC}}$ estimates show a highly positive skew ( $\mathrm{SK}>$ $1)$. In terms of kurtosis-relative comparison of tail shape to that of a normal distribution (Westfall 2014) - the CGF-derived estimates of CBD and TDF have KU values in the range of 2.13 to 2.79 , which indicates platykurtic distributions that are substantially flatter and wider with shorter, thinner tails than that of a normal distribution $(\mathrm{KU}=3)$. The $\mathrm{CBD}_{\mathrm{FC}}$ 
Table 4 The number $(n)$ and relative proportion (\% of total) of satellite predictors (optical, estimates of basal area [BA], and synthetic aperture radar [SAR]) retained by each canopy bulk density (CBD) and total fuel density (TFD) model during calibration in this Minnesota, USA, study (2015 to 2016) to quantify coniferous forest fuels. Subscript notations 1, 12, and 123 reference the zenith angle range of canopy gap fraction measurements ( 0 to $7^{\circ}, 0$ to $23^{\circ}$, and 0 to $38^{\circ}$, respectively) used to estimate field fuel density, while FC represents FuelCalc-derived estimates of CBD. A further breakdown of the SAR predictors into C-band, L-band, and C to $L$ ratios is shown in italics. Dashes (-) indicate groups of SAR predictors not used during calibration for two fuel density models

\begin{tabular}{|c|c|c|c|c|c|c|c|c|c|c|c|c|c|c|}
\hline \multirow{2}{*}{$\begin{array}{l}\text { Satellite } \\
\text { variable }\end{array}$} & \multicolumn{2}{|c|}{$\mathrm{TFD}_{1}$} & \multicolumn{2}{|c|}{$\mathrm{TFD}_{12}$} & \multicolumn{2}{|c|}{$\mathrm{TFD}_{123}$} & \multicolumn{2}{|c|}{$\mathrm{CBD}_{1}$} & \multicolumn{2}{|c|}{$\mathrm{CBD}_{12}$} & \multicolumn{2}{|c|}{$\mathrm{CBD}_{123}$} & \multicolumn{2}{|c|}{$\mathrm{CBD}_{\mathrm{FC}}$} \\
\hline & $n$ & $\%$ & $n$ & $\%$ & $n$ & $\%$ & $n$ & $\%$ & $n$ & $\%$ & $n$ & $\%$ & $n$ & $\%$ \\
\hline Optical & 5 & 45.5 & 4 & 23.5 & 6 & 27.3 & 12 & 37.5 & 15 & 41.7 & 17 & 44.7 & 13 & 44.8 \\
\hline BA & 2 & 18.2 & 2 & 11.8 & 6 & 27.3 & 4 & 12.5 & 7 & 19.4 & 5 & 13.2 & 4 & 13.8 \\
\hline SAR & 4 & 36.4 & 11 & 64.7 & 10 & 45.5 & 16 & 50.0 & 14 & 38.9 & 16 & 42.1 & 12 & 41.4 \\
\hline C-band & - & - & 8 & 47.1 & 7 & 31.8 & 7 & 21.9 & 7 & 19.4 & 8 & 21.1 & 6 & 20.7 \\
\hline L-band & 1 & 9.1 & - & - & 1 & 4.5 & 5 & 15.6 & 5 & 13.9 & 6 & 15.8 & 3 & 10.3 \\
\hline$C$ to $L$ ratio & 3 & 27.3 & 3 & 17.6 & 2 & 9.1 & 4 & 12.5 & 2 & 5.6 & 2 & 5.3 & 3 & 10.3 \\
\hline Total & 11 & & 17 & & 22 & & 32 & & 36 & & 38 & & 29 & \\
\hline
\end{tabular}

estimates show an opposite trend $(\mathrm{KU}=3.93)$, which suggests longer, relatively flatter tails compared to normal (leptokurtic). The $\mathrm{CBD}_{\mathrm{LF}}$ estimates extracted for our field plot locations show a distinctly uniform distribution trend $(\mathrm{KU}=0.26)$, which is considered highly leptokurtic (Fig. 6).

Understory conifer biomass and overstory forest structure Of the 3738 conifer trees measured in this study across 61 field plots, 70\% (2617) were balsam fir; of these, $50.4 \%$ were $<2 \mathrm{~m}$ tall, with an additional $15.6 \%$ in the 2 to $3 \mathrm{~m}$ range and $9.7 \%$ in the 3 to $4 \mathrm{~m}$ height range (i.e., $75.7 \%$ of balsam fir were $\leq 4 \mathrm{~m}$ tall). Mean understory coniferous biomass (needles, branches, and boles) within two separate vertical aggregations $(0$ to $2 \mathrm{~m}$ and 0 to 3 $\mathrm{m}$ AGL) did not show any significant differences $(P=$
0.291 to 0.978 ), according to Tukey's HSD test, when grouped by two broad overstory forest types (broadleaf and mixed broadleaf-conifer) or two overstory percent canopy cover ranges ( 47 to $66 \%$ and 67 to $78 \%$ ).

\section{Discussion}

Canopy gap fraction and canopy bulk density

The ability to model and map CBD via indirect CGF measurements hinges on the relationship between such measures, leaf area index (LAI), and canopy biomass (Brown 1978; Keane et al. 2005). However, CGF measured by the LAI-2200C and similar instruments tends to underestimate LAI, especially for conifers (Bolstad and Gower 1990; Gower and Norman 1991). Thus, branches and species-specific clumping of needles around shoots blocking the direct view of some fraction

Table 5 Satellite image to ground total fuel density (TFD; $\mathrm{kg} \mathrm{m}^{-3}$ ) and canopy bulk density $\left(C B D ; \mathrm{kg} \mathrm{m}^{-3}\right.$ ) model calibration results using field data collected in 2015 and 2016. Results used to evaluate the potential for mapping coniferous fuel density across the Superior National Forest, Minnesota, USA. Models for TFD and CBD are denoted T and C, respectively, while numbers 1, 12, and 123 reference the zenith angle range used for canopy gap fraction measurements: 0 to $7^{\circ}, 0$ to $23^{\circ}$, and 0 to $38^{\circ}$, respectively. FuelCalc-derived estimates of CBD are denoted FC. LANDFIRE's CBD estimates (LF) for our plot locations are shown for comparison; dashes (-) indicate no data. Descriptive model statistics include mean and maximum (Max) fuel density $\left(\mathrm{kg} \mathrm{m}^{-3}\right)$, standard deviation (SD), adjusted coefficient of determination $\left(\mathrm{Adj} R^{2}\right.$ ), root mean squared error (RMSE; $\mathrm{kg} \mathrm{m}^{-3}$ ), cross-validation predicted error sum of squared (PRESS), Akaike information criterion (AIC), and Bayesian information criterion (BIC). The number of initial (iVar) and final ( $\mathrm{V}$ ar) image predictor variables retained and the number of latent component variables (Comp) used in each of the final models are given

\begin{tabular}{|c|c|c|c|c|c|c|c|c|c|c|c|}
\hline Model & Mean & Max & SD & iVar & fVar & Comp & Adj $R^{2}$ & RMSE & PRESS & AIC & $\mathrm{BIC}$ \\
\hline LF & 0.108 & 0.300 & 0.048 & - & - & - & - & - & - & - & - \\
\hline FC & 0.999 & 2.991 & 0.787 & 66 & 29 & 25 & 0.961 & 0.165 & 0.375 & -155.0 & 125.5 \\
\hline $\mathrm{T} 1$ & 0.669 & 1.037 & 0.154 & 66 & 11 & 3 & 0.340 & 0.122 & 0.833 & -226.0 & 53.3 \\
\hline T12 & 1.432 & 2.466 & 0.435 & 66 & 16 & 15 & 0.769 & 0.209 & 0.631 & -152.9 & 71.6 \\
\hline T123 & 2.158 & 3.468 & 0.726 & 66 & 23 & 18 & 0.869 & 0.242 & 0.575 & -121.3 & 99.5 \\
\hline $\mathrm{C} 1$ & 0.472 & 0.934 & 0.210 & 66 & 32 & 24 & 0.950 & 0.048 & 0.463 & -299.7 & 142.9 \\
\hline $\mathrm{C} 12$ & 1.035 & 2.492 & 0.583 & 66 & 36 & 28 & 0.974 & 0.072 & 0.418 & -236.9 & 157.3 \\
\hline $\mathrm{C} 123$ & 1.596 & 3.000 & 0.743 & 66 & 38 & 30 & 0.978 & 0.103 & 0.378 & -194.3 & 164.2 \\
\hline
\end{tabular}




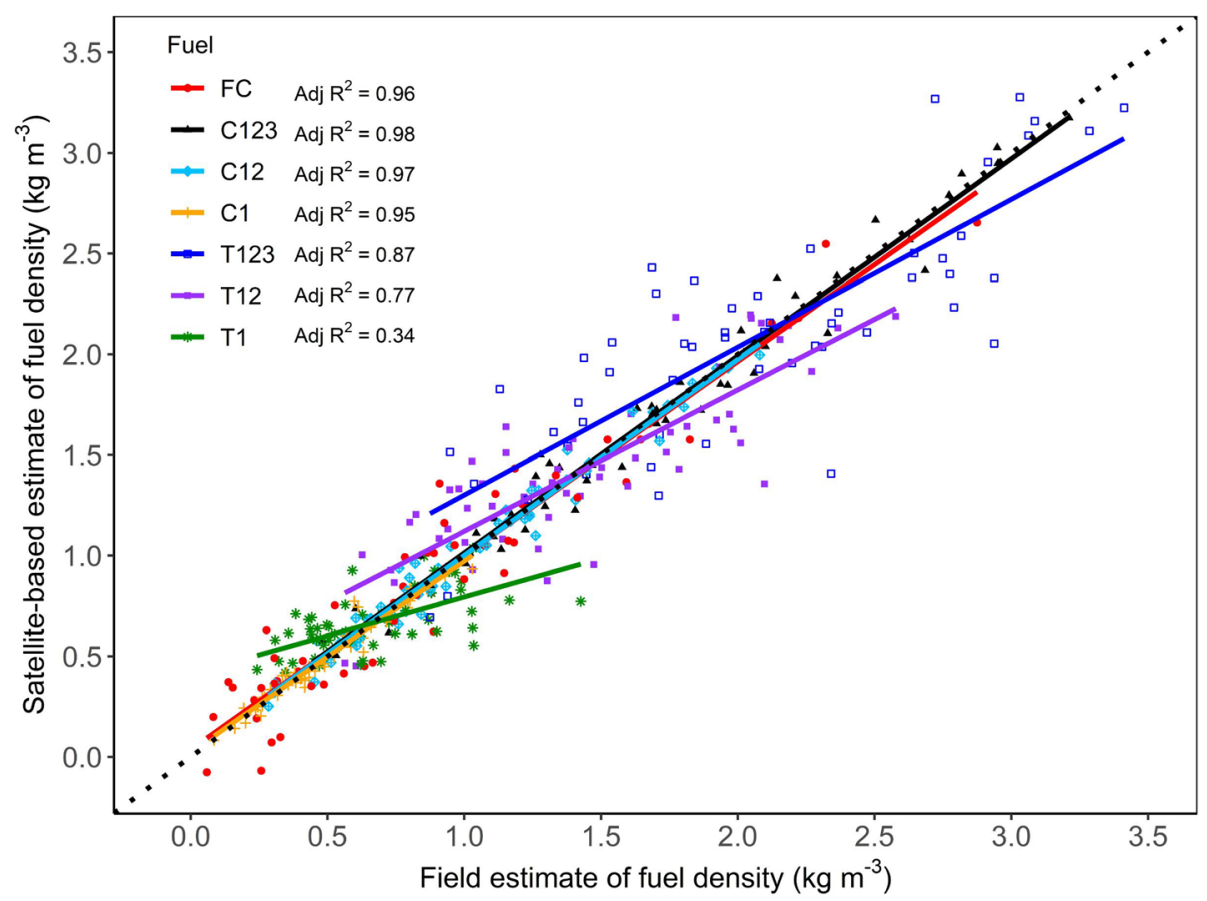

Fig. 4 Regression results between field estimates and satellite-derived estimates of total fuel density (TFD; $\mathrm{kg} \mathrm{m}^{-3}$ ) and canopy bulk density (CBD; $\mathrm{kg} \mathrm{m}^{-3}$ ) used for mapping fuel within the Superior National Forest, Minnesota, USA, following field data collection in 2015 and 2016 . Models of TFD (coniferous fuels above ground level) and CBD (coniferous fuels $2 \mathrm{~m}$ above ground level) based on weighted canopy gap fraction are denoted $T$ and $C$, respectively, while numbers 1,12 , and 123 refer to zenith angle ranges ( 0 to $7^{\circ}, 0$ to $23^{\circ}$, and 0 to $38^{\circ}$, respectively) of the LAl-2200C instrument. FuelCalc-based estimates of CBD are denoted FC. The dotted black line represents unity between field-measured and satellite-calibrated estimates of fuel density

of needles in an instrument's optical field of view have been suggested (Gower and Norman 1991; White et al. 1997). However, Fassnacht et al. (1994) found no improvements in modeling conifer LAI when specific clumping bias factors (sensu Gower and Norman 1991; Stenberg et al. 1994) were employed. Interestingly, Gower and Norman (1991) speculated that the impact of needle-bearing branches on CGF and LAI is likely small due to foliar masking effects. Keane et al. (2005) went further and suggested that skyward projection of foliage may largely block the view of small and large supportive branch tissues. Their speculation arose from the fact that only small differences in predicted $C B D$ values (i.e., maximum $C B D$ measured within any $1-\mathrm{m}$ increment up to tree top) were obtained when using LAI-2000 CGF measurements (collected at $2 \mathrm{~m} \mathrm{AGL}$ ) across different aggregations of canopy biomass data (e.g., foliage alone; foliage + small, burnable branches; and foliage plus all branches). Thus, the use of CGF as a basis for the determination of CBD, while not perfect, may be robust to species-specific differences among coniferous fuel structures.

\section{Disparity among CBD estimates: CGF, FuelCalc, and LANDFIRE} We developed field estimates of CBD in the SNF via two methods: allometric modeling via the FuelCalc routine and transformation of CGF according to Keane et al. (2005), in which the authors meticulously calibrated CGF-to-CBD models based on the iterative destructive sampling of Western conifer stands to determine the amount of biomass removed and amount of biomass that remained. We extended the use of their methodologies and equations to model field estimates of CBD using the 0 to $7^{\circ}(1)$ and 0 to $23^{\circ}(12)$ zenith angle ranges for comparison to their 0 to $38^{\circ}$ (123) models. Of the $\mathrm{CBD}$ models, $\mathrm{CBD}_{123}$ most closely approximated field estimates of $\mathrm{CBD}$ obtained using FuelCalc $\left(\mathrm{CBD}_{\mathrm{FC}}\right.$; Figs. 4 and 5). However, the $\mathrm{CBD}_{123}$ model produced estimates that far exceed values believed to be typical for this region (see Engelstad et al. 2019). In this study, the upper range among CBD estimates increases substantially with increasing LAI-2200C sensor zenith angle (Fig. 4). In this respect, the $\mathrm{CBD}_{1}$ model produced a more realistic range of estimates, while the $\mathrm{CBD}_{12}$ model was intermediate between the extremes (Fig. 4, Table 5).

Fire managers on the SNF suspect that actual CBD values do exceed that which LANDFIRE portrays due to the abundance of lower canopy fuels (e.g., 2 to $4 \mathrm{~m}$ AGL), but lack a definitive set of sampling data to reinforce such conjecture (P. Johnson, USDA Forest Service, Grand Marais, MN, USA, unpublished data). 


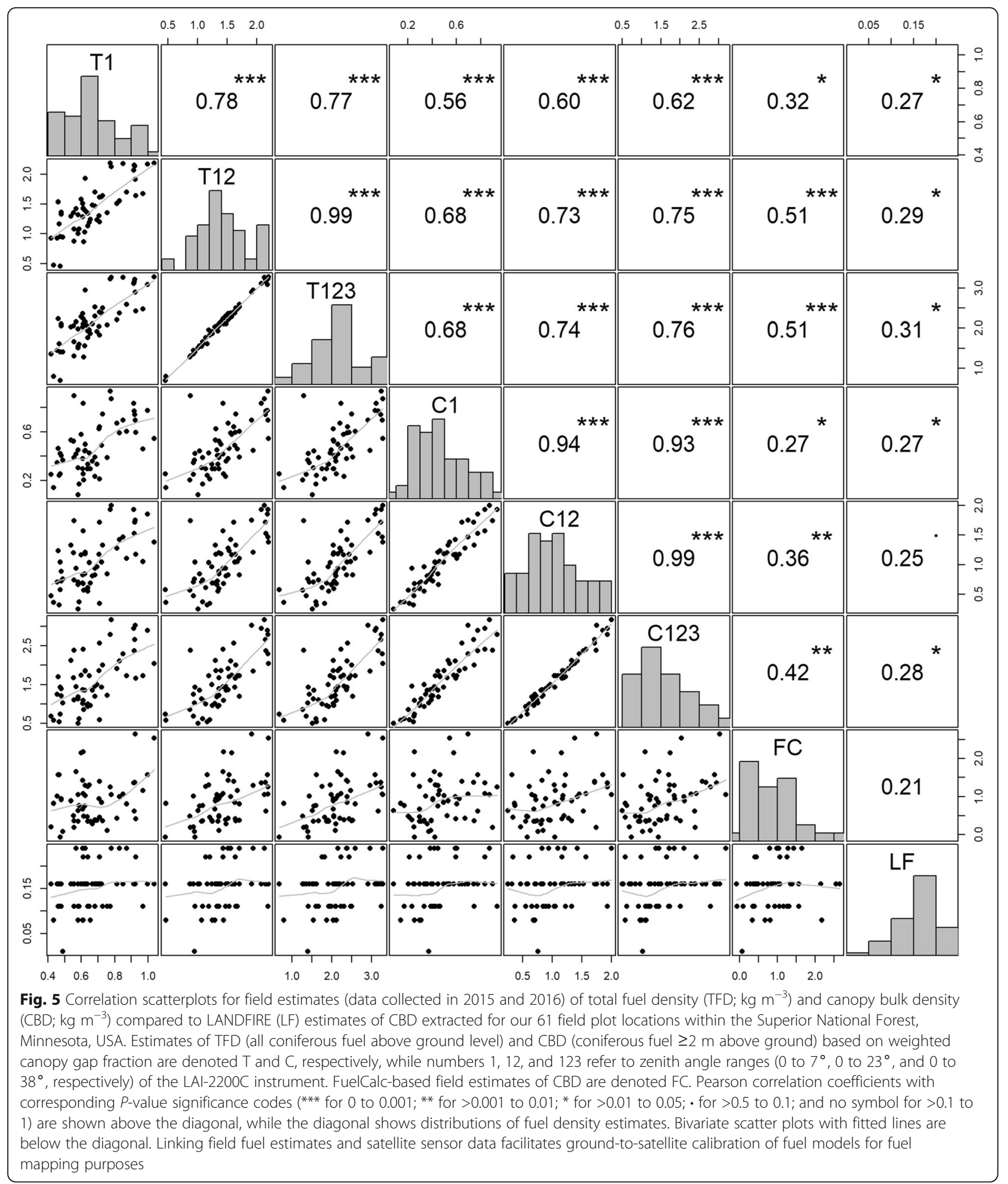

Moreover, according to our findings, modeling the distribution and abundance of such fuels in the SNF based on overstory canopy characteristics may not be a viable mapping option. Current versions of FuelCalc conservatively overestimate $\mathrm{CBD}$ by using the maximum $\mathrm{CBD}$ found within any $3.5-\mathrm{m}$ layer of the canopy, a value that often exceeds twice the profile average (Scott and Reinhardt 2005; Scott 2008). This is in response to both fire spread sensitivity to maximum CBD (Keane et al. 2005) and underlying issues with fire spread equations (van 


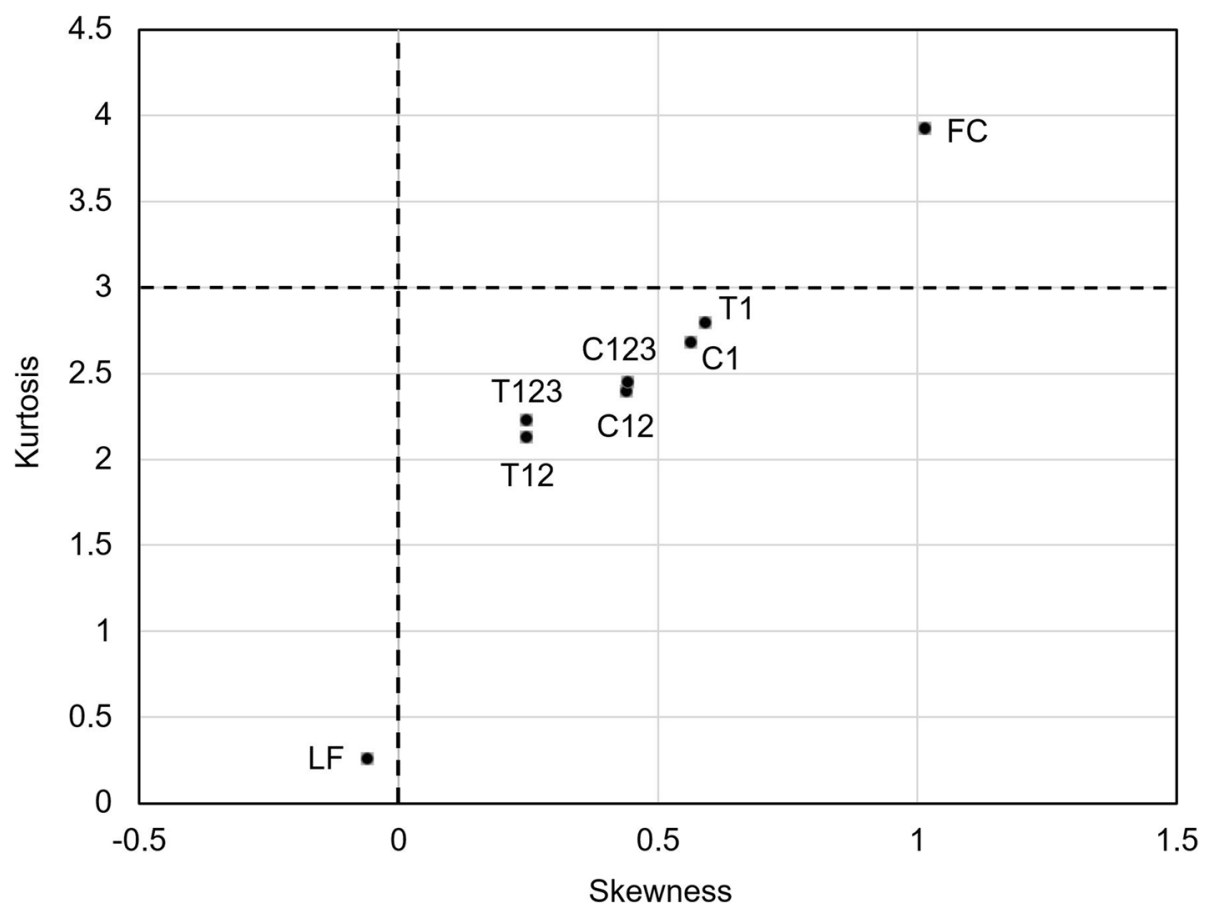

Fig. 6 Skewness and kurtosis measures (both unitless) of frequency distribution shape for respective estimates of fuel density (labeled dots). Shape statistics for total fuel density (TFD) and canopy bulk density (CBD) based on weighted canopy gap fraction are denoted T and C, respectively, while numbers 1,12 , and 123 refer to zenith angle ranges $\left(0\right.$ to $7^{\circ}, 0$ to $23^{\circ}$, and 0 to $38^{\circ}$, respectively) of the $\mathrm{LAl}-2200 \mathrm{C}$ instrument. Shape statistics for FuelCalc-based estimates of CBD are denoted as FC, while LANDFIRE CBD is denoted LF. Dashed lines indicate zones of relative normality for the respective shape metrics. Field data for these analyses were collected in 2015 and 2016 and combined with satellite sensor data to calibrate models for mapping fuel density across the Superior National Forest, Minnesota, USA

Wagner 1977; Rothermel 1991). In this study, however, average estimates for $\mathrm{CBD}_{\mathrm{FC}}$ were over nine times greater than average $\mathrm{CBD}_{\mathrm{LF}}$ across our study area (Table 5). Hence, we suspect that the actual CBD values for the SNF region lie somewhere between these estimates. Irrespective of such conjecture, it is curious that Pearson correlations between the two CBD estimates are neither significant nor marginally significant (Fig. 5).

Whether such offsets are linked to the substitution of functionally similar conifer species (Western for Eastern) within the FuelCalc routine or some other factor such as inappropriate use of canopy closure rather than canopy cover during the calculation of $\mathrm{CBD}_{\mathrm{LF}}$ driving values downward (Scott 2008) is difficult to determine. Early in our investigation, we questioned FuelCalc's use of Douglas-fir (Pseudotsuga menziesii [Mirb.] Franco) allometry over Engelmann spruce as a substitution for black spruce. However, even higher estimates of CBD resulted when we substituted Engelmann spruce allometry. Similar questions arose for other species having low abundance on this landscape. However, for conifer species that do dominate this landscape (Fig. 7), we had no defensible reason to question FuelCalc's substitutions. Nevertheless, while we assumed FuelCalc-derived estimates of CBD were quasi-ground truth in this research, we suspect that some Western species substitutions for Eastern species that lacked detailed allometry may represent a potential flaw in these analyses. Hence, detailed allometric equations that afford accurate, region-specific estimation of CBD for common Eastern conifer species remain a research need.

\section{Effects of CGF measurement level on fuel density estimation}

The collection of CGF data from $2 \mathrm{~m}$ AGL to estimate CBD (Keane et al. 2005), LAI (Fassnacht et al. 1994), and other forest canopy parameters (Paletto and Tosi 2009) is standard practice, while the collection of ground-level CGF for these purposes is not. This region of the SNF has a high abundance of understory coniferous fuel (mainly balsam fir) that straddles the 2-m AGL fuel boundary between surface and canopy fuels. As such, we used groundlevel CGF measurements to enable overall assessment of the sensitivity of satellite sensor data (especially SAR) to canopy fuel biomass (CBD) and coniferous surface fuel density (SFD). That said, the most dramatic differences among CGF-based fuel density models were between levels of CGF measurement (0 versus $2 \mathrm{~m}$ AGL) rather than between the LAI-2200C sensor's fields of view (0 to $7^{\circ}$ [1], 0 to $23^{\circ}[12]$, and 0 to $38^{\circ}$ [123]). In regression 


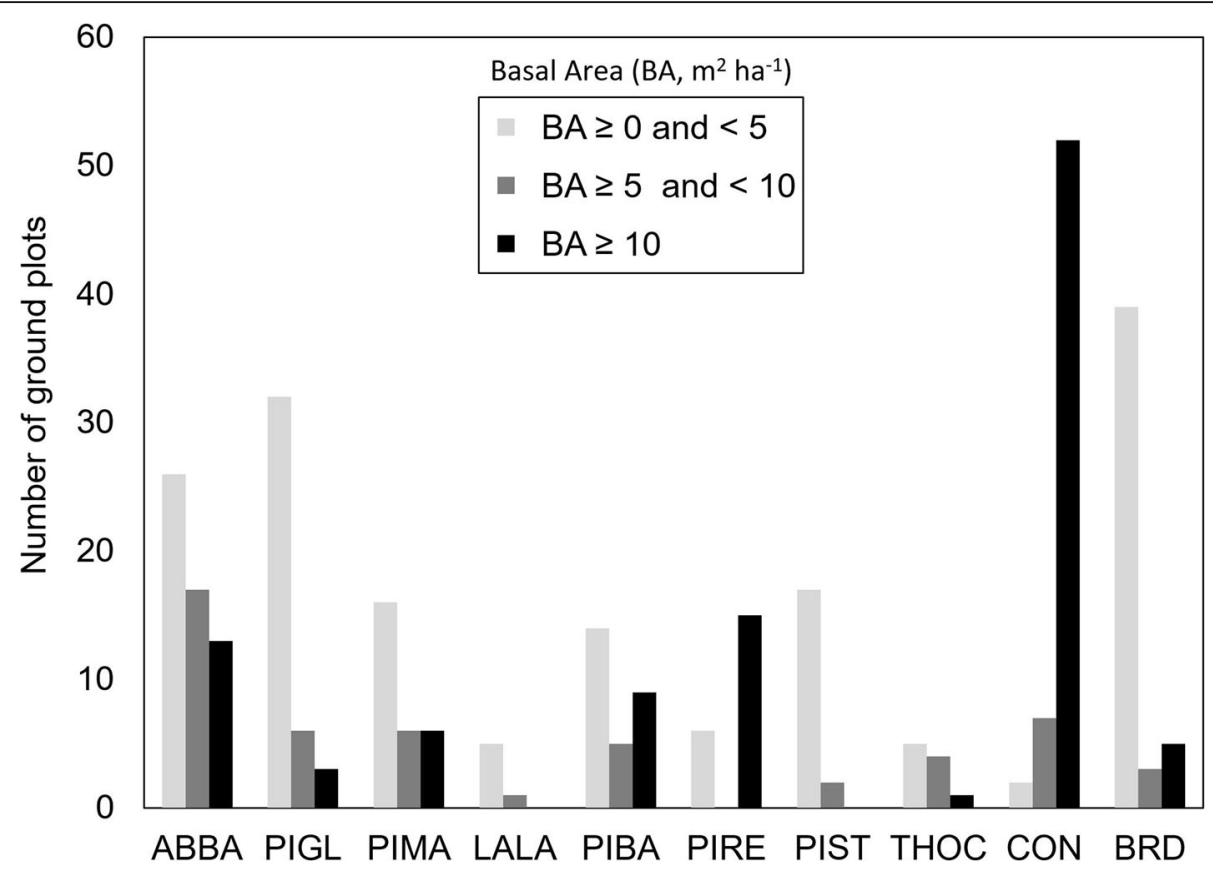

Fig. 7 Distribution of forest basal area $\left(B A ; \mathrm{m}^{2} \mathrm{ha}^{-1}\right)$ showing the relative abundance of conifer and broadleaf forest associates among 61 random field plots sampled in 2015 and 2016 within the Superior National Forest, Minnesota, USA. Shown are three forest BA levels (0 to 5, 5 to 10, and $\geq 10 \mathrm{~m} \mathrm{ha}^{-1}$ ) for eight conifer species and two generalized forest groups: conifer (CON) and broadleaf (BRD). Sampled conifer species include balsam fir (ABBA), white spruce (PIGL), black spruce (PIMA), tamarack (LALA), jack pine (PIBA), red pine (PIRE), eastern white pine (PIST), and northern white cedar (THOC)

analyses, field-based estimates and satellite-based estimates of fuel density for all TFD models deviated from unity, showing both additive and multiplicative shifts between dependent TFD variables and independent, satellite-based estimates of TFD (Fig. 4). In contrast, all satellite-based estimates of CBD followed unity with field estimates of CBD via CGF (Fig. 4).

For TFD models, two complementary explanations for deviations from unity with ground-based estimates arise. First, based largely on failure of all SFD model calibrations, we suspect that contributions of smaller, understory conifer saplings to estimates of TFD were not effectively detected by either optical or SAR satellite sensors, in spite of the relative retention difference among SAR predictors observed for TFB and CBD calibrations (Table 4). As such, TFD model calibrations between ground and satellite sensor data remained possible because some portion of canopy fuel structures were visible to SAR sensors and, to a lesser degree, by optical sensors, which we posit was not the case for SFD. Second, with respect to ground-level CGF measurements, we suspect that TFD is biased by live, coniferous surface and lower canopy fuels (e.g., saplings) when present. If true, this may preclude field estimation of SFD (i.e., TFD minus CBD) via CGF metrics, which comports with prior research (Gower and Norman 1991; Fassnacht et al. 1994).
With respect to CBD, we suspect that burnable fuel in lower layers of the forest canopy above $2 \mathrm{~m}$ AGL (saplings and lower branches of mature trees) in this sub-boreal landscape represents a substantial fuel biomass gap that remains hidden from remote detection, space-based SAR sensors notwithstanding. While generally accepted as dogma for passive optical sensors such as Landsat OLI (Keane et al. 2005), we suspect that lower canopy fuel detection via the current suite of SAR sensors is also limited due to a combination of C- and L-band wavelength idiosyncrasies with respect to forest cover (Le Toan et al. 1992; Imhoff 1995; Sadeghi et al. 2018). For instance, Lband $(23.6 \mathrm{~cm} \lambda)$ backscatter from relatively dense, mature forests of typical basal area (e.g., 20 to $30 \mathrm{~m}^{2} \mathrm{ha}^{-1}$ ) corresponds, in decreasing order, to the abundance of larger canopy components (boles and larger branches); groundtrunk double bounce; and, to a lesser degree, depending on canopy cover, the ground (Wang et al. 1995; Ustin 2004). Hence, smaller canopy components, such as overstory foliage and understory conifer saplings (e.g., balsam fir) remain largely undetected at L-band wavelengths (see Imhoff 1995). For larger trees, however, known relationships between bole dimension, basal area, and CBD (Duveneck and Patterson III 2007; Fernández-Alonso et al. 2013) may partially explain the retention of L-band predictors during CBD calibrations (Table 3). At C-band 
$(5.54 \mathrm{~cm} \lambda)$, for the same forest scenario, the scattering phase center is primarily a function of smaller components in the upper forest canopy, including foliage and small branches (Wang et al. 1993; Pulliainen et al. 1999; Sexton et al. 2009). This limits canopy penetration to a fraction of overall canopy depth (Kellndorfer et al. 2004; Sadeghi et al. 2018). Therefore, conjecture regarding the relative significance of SAR predictor retention differences between TFD and CBD model calibrations (Tables 3 and 4) would be unwise.

\section{Recommendations for the fire modeling community}

Given the discussion above, we believe that $\mathrm{CBD}_{1}$ and $\mathrm{CBD}_{12}$, derived via transformed CGF data according to Keane et al. (2005), represent the most promising estimates of burnable canopy fuel in the SNF. In spite of potential allometric differences in burnable biomass between Eastern conifers and their Western substitutes, the majority of $\mathrm{CBD}_{\mathrm{FC}}$ estimates lie within the combined range of these two indirect estimates of CBD (Fig. 4). Moreover, the SAR sensor data used in this study to scale field estimates of CBD to the SNF landscape do not appear biased to the presence of underlying coniferous surface fuels. Hence, we recommend testing these CGF-based estimates of $\mathrm{CBD}$ as well as $\mathrm{CBD}_{\mathrm{FC}}$ in the Upper Midwest within the FARSITE modeling framework to evaluate and understand potential fire behavior sensitivity to these different fuel inputs. What seems to be of high importance when modeling fire behavior is having CBD values high enough to propagate fire across a landscape (Scott 2008). Critical CBD thresholds that, when exceeded, support active crown fire behavior vary according to fine fuel moisture content and 10-m wind speed (Agee 1996; Cruz et al. 2005). For Western coniferous forests, this may range from $0.05 \mathrm{~kg} \mathrm{~m}^{-3}$ at $4 \%$ fuel moisture and $25 \mathrm{~km} \mathrm{~h}^{-1}$ wind speed to as high as $0.30 \mathrm{~kg} \mathrm{~m}^{-3}$ at the same fuel moisture and $\sim 2 \mathrm{~km} \mathrm{~h}^{-1}$ wind speed (Cruz et al. 2005). Hence, with respect to fire behavior modeling in the SNF, our estimates of CBD certainly seem high enough to propagate fire at almost any wind speed. However, the potential importance and impact of various differences in fuel distribution and density among our estimates of CBD across this landscape (Figs. 5 and 6), which may affect rates of fire spread (Agee 1996), remain untested.

\section{Ladder fuels}

Remote detection of coniferous ladder fuels (surface and lower canopy) in the Upper Midwest remains a challenge using either low-density lidar (Engelstad et al. 2019) or dual-polarity C- and L-band SAR satellite sensor data. The distribution and abundance of ladder fuels within the SNF landscape (Fig. 8) represent a substantial gap in knowledge that affects

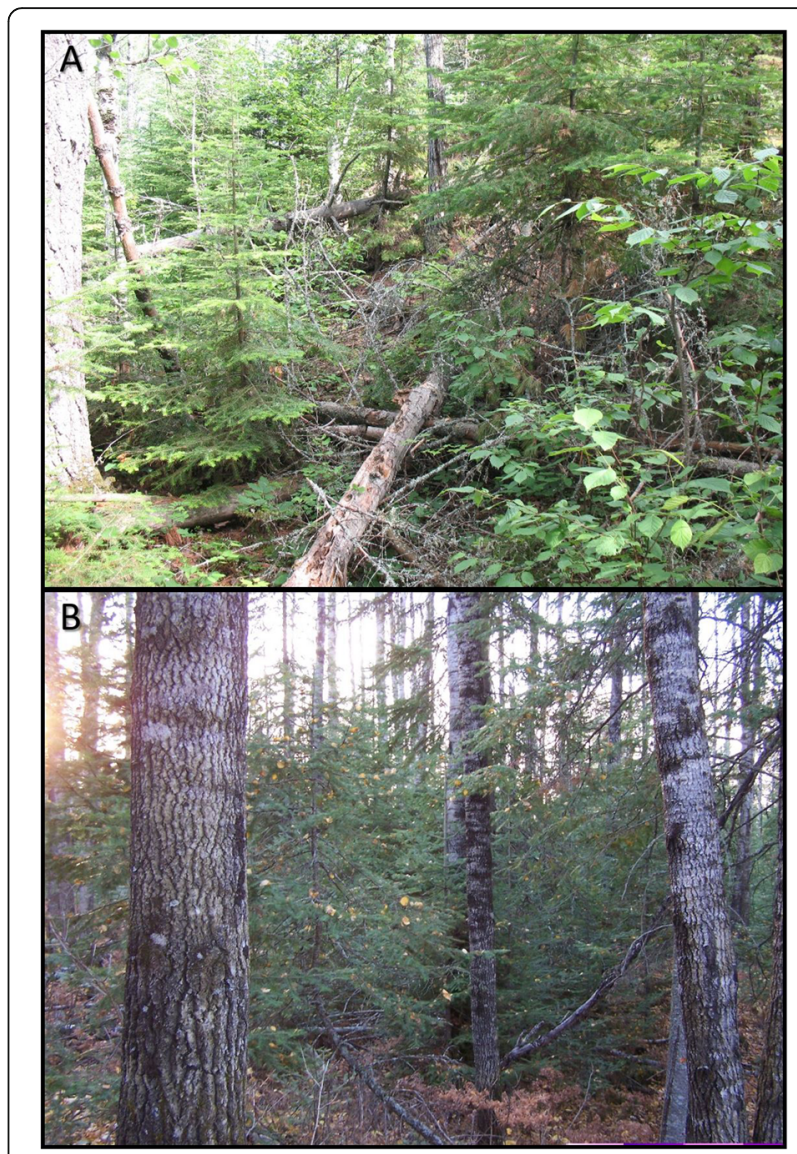

Fig. 8 Example photos of conifer ladder fuels (primarily balsam fir, Abies balsamea [L.] Mill.) taken by Patricia J. Johnson in 2016 within the Gunflint Ranger District of the Superior National Forest,

Minnesota, USA, under a mixed conifer-broadleaf overstory and $\mathbf{b}$ pure broadleaf overstory. One goal of this research was to

determine the impact of coniferous surface and lower canopy fuels on satellite-based detection and mapping of canopy bulk density $\left(\mathrm{CBD} ; \mathrm{kg} \mathrm{m}^{-3}\right)$ in this region using indirect measurements of CBD as ground truth

the efficiency of efforts focused on fuel reduction treatments to mitigate wildfire risk. Research on linkages between the abundance of understory biomass and combinations of overstory canopy type and percent cover (Messier et al. 1998; Légaré et al. 2002) begs the question of whether modeling the presence of ladder fuels may be possible in this region. We suspect that positive understory light-to-biomass relationships likely hold true regarding broadleaf biomass in this region. However, the results of our analyses do not support the possibility of modeling balsam fir ladder fuels via this mechanism due to its strong shade tolerance (Corace et al. 2012). Low-density lidar sensor data (i.e., average of 0.44 points $\mathrm{m}^{-2}$ ) have not yet facilitated sufficient characterization of such ladder fuels in this region (Engelstad et al. 2019) to enable sound management decisions. Resolution of this 
gap in fuel information will likely only be resolved once higher-density lidar data (e.g., 8 points $\mathrm{m}^{-2}$ ) are available on a more frequent basis-a project that is currently underway in Minnesota (MNGAC [Minnesota Geospatial Advisory Council] 2020).

\section{Conclusions}

In an attempt to capture coniferous fuel structures beyond optical detection limits, as suggested by some researchers (Keane et al. 2005; Keane et al. 2006), we combined dual-polarity C- and L-band synthetic aperture radar (SAR) with leaf-off optical satellite sensor data to achieve deeper detection depth into forest fuel structures. Satellite data were coupled with both FuelCalcbased estimates of CBD and indirect, CGF-based, field estimates of CBD, TFD (all burnable fuels above ground level), and SFD (i.e., TFD minus CBD) to calibrate fuel models to evaluate fuel structure mapping capabilities. Among the indirect methods, the slope of fuel density estimates (observed versus predicted) was highly sensitive to the elevation of CGF measurements $(0 \mathrm{~m}$ versus $2 \mathrm{~m}$ AGL), while the magnitude of fuel density estimates was sensitive to the field of view of the LAI-2200C CGF sensor. We believe that the presence of understory balsam fir (e.g., $\leq 3$ to $4 \mathrm{~m}$ tall) attenuated the ground-level view of the LAI-2200C instrument, causing substantial bias in predicting TFD. This partially contributed to the failure of all SFD model calibrations with satellite sensor data, in addition to known canopy penetration limits associated with C-band SAR (Kellndorfer et al. 2004; Sadeghi et al. 2018). At the same time, it is likely that lower strata biomass structures (boles and large branches) are invisible at L-band wavelengths (see Imhoff 1995). Thus, for larger trees, we suspect that the relationship between bole dimension, basal area, and CBD (Duveneck and Patterson III 2007; Fernández-Alonso et al. 2013) may be linked to the retention of L-band predictors during CBD model calibrations (Tables 3 and 4).

Models of CBD derived via CGF data did not suffer equally from suspected lower fuel bias issues, as all showed better unity between field-derived and satellitepredicted estimates of CBD. However, the maximum range of modeled $\mathrm{CBD}$ remained sensitive to the zenith angle ranges of the LAI-2200C instrument. While the 0 to $38^{\circ}$ zenith angle range produced statistically superior CBD calibrations with satellite sensor data and were most similar to $\mathrm{CBD}_{\mathrm{FC}}$ estimates, both $\mathrm{CBD}_{123}$ and $\mathrm{CBD}_{\mathrm{FC}}$ produced suspiciously high upper ranges of CBD. Canopy gap fraction measured at 0 to $7^{\circ}$ and 0 to $23^{\circ}$ zenith angle ranges each produced a more reasonable range of $\mathrm{CBD}$ values for this region. However, the importance of spatial variability among these CGFderived CBD estimates on actual fire behavior modeling remains unknown. With respect to FuelCalc, substitution of Western for Eastern conifer species' allometry in the calculation of CBD represents an unknown effect on these analyses. Hence, a need exists for the development of region-specific CBD allometry.

A substantial amount of coniferous biomass in the SNF region resides in the understory layers below the dominant overstory canopy. Much of this biomass straddles the 2-m AGL categorical boundary between surface fuels and canopy fuels, each of which is largely hidden from the view of optical and SAR sensors. Unlike other regions of the USA, the abundance of understory coniferous biomass, especially balsam fir, in the SNF appears to be insensitive to both overstory forest type (broadleaf versus broadleaf-conifer mix) or percent canopy cover. This contradicts current dogma (Zavitkovski 1976; Messier et al. 1998; Légaré et al. 2002) and is likely due to the strong shade tolerance of balsam fir.

\section{Acknowledgements \\ The authors would like to recognize personnel at the Gunflint Ranger Station of the Superior National Forest for assistance in generating random plot locations for this effort. We also appreciate the many informative \\ consultations and advice graciously offered by Dr. R. Keane over the course of this effort.}

\section{Authors' contributions}

PW performed all fieldwork. PW and JO developed the basic methodology, performed image analyses, and conducted data analyses. All authors read and approved the final manuscript.

\section{Funding}

This research was made possible via a cooperative research grant from the USDA Forest Service (15-CS-11090902-040), a USDA McIntire Stennis Capacity Grant (project IOW5348), and lowa State University's Department of Natural Resource Ecology and Management.

\section{Availability of data and materials}

The corresponding author will provide images of various CBD estimates and point shapefiles of ground plots (with extracted satellite sensor data values, field CGF values, and FuelCalc-derived CBD estimates) used for model calibrations upon request.

\section{Declarations}

Ethics approval and consent to participate

Not applicable.

Consent for publication

Not applicable.

\section{Competing interests}

The authors declare that they have no competing interests.

\section{Author details}

'Department of Natural Resource Ecology and Management, lowa State University, 2310 Pammel Drive, Ames, IA 50011, USA. 'USDA Forest Service, Gunflint Ranger District, Superior National Forest, 2020 West Hwy 61, Grand Marais, MN 55604, USA.

Received: 16 June 2020 Accepted: 14 June 2021

Published online: 08 October 2021

\section{References}

Abbas, D., D. Current, M. Ryans, S. Taff, H. Hoganson, and K.N. Brooks. 2011. Harvesting forest biomass for energy - An alternative to conventional fuel 
treatments: Trials in the Superior National Forest, USA. Biomass and Bioenergy 35 (11): 4557-4564. https://doi.org/10.1016/j.biombioe.2011.06.030.

Agee, J.K. 1996. The influence of forest structure on fire behavior. In Proceedings of the 17th annual forest vegetation management conference. University of California, Agriculture and Natural Resources, 16-18 January 1996, Redding, California, 52-68.

Akaike, H. 1973. Information theory and an extension of the maximum likelihood principle. In 2nd international symposium on information theory. 2-8 September 2-8, 1971 Tsahkadsor, Armenia, USSR, ed. B.N. Petrov and F. Csaki, 267-281.

Alexander, M.E. 1988. Help with making crown fire hazard assessments. Pages 147-156 in W.C. Fischer and S.F. Arno, compilers. Protecting people and homes from wildfire in the Interior West., October 6-8, 1987, Missoula, Montana, USA. USDA Forest Service General Technical Report GTR-INT-251. Ogden: USDA Forest Service, Intermountain Research Station.

Andersen, H.E., R.J. McGaughey, S.E. Reutebuch, and S.E. 2005. Estimating forest canopy fuel parameters using LIDAR data. Remote Sensing of Environment 94 (4): 441-449. https://doi.org/10.1016/j.rse.2004.10.013.

Anderson, J.R. 1976. A land use and land cover classification system for use with remote sensor data. U.S. Geological Survey Professional Paper 964. Reston: U.S. Geological Survey. https://doi.org/10.3133/pp964.

Baker, W.L. 1989. Landscape ecology and nature reserve design in the Boundary Waters Canoe Area, Minnesota. Ecology 70 (1): 23-35. https://doi.org/10.23 07/1938409.

Bolstad, P.V., and S.T. Gower. 1990. Estimation of leaf area index in fourteen southern Wisconsin forest stands using a portable radiometer. Tree Physiology 7 (1-2-3-4): 115-124. https://doi.org/10.1093/treephys/7.1-2-3-4.115.

Breiman, L. 2001. Random forests. Machine Learning 45 (1): 5-32. https://doi.org/1 0.1023/A:1010933404324.

Brown, J.K. 1978. Weight and density of crowns of Rocky Mountain conifers. USDA Forest Service Research Paper INT-197. Ogden: USDA Forest Service, Intermountain Forest and Range Experiment Station. https://doi.org/10.5962/ bhl.title.68796.

Bulmer, M.G. 1979. Principles of statistics. Mineola: Dover Publications.

Cook, R.D. 1979. Influential observations in linear regression. Journal of the American Statistical Association 74 (365): 169-174. https://doi.org/10.1080/01 621459.1979 .10481634$.

Corace, R.G., L.M. Shartell, L.A. Schulte, W.L. Brininger, M.K. McDowell, and D.M. Kashian. 2012. An ecoregional context for forest management on National Wildlife Refuges of the Upper Midwest, USA. Environmental Management 49 (2): 359-371. https://doi.org/10.1007/s00267-011-9776-3.

Cruz, M.G., M.E. Alexander, and R.H. Wakimoto. 2003. Assessing canopy fuel stratum characteristics in crown fire prone fuel types of western North America. International Journal of Wildland Fire 12 (1): 39-50. https://doi.org/10.1071/NF02024.

Cruz, M.G., M.E. Alexander, and R.H. Wakimoto. 2005. Development and testing of models for predicting crown fire rate of spread in conifer forest stands. Canadian Journal of Forest Research 35 (7): 1626-1639. https://doi.org/10.113 9/×05-085

Duveneck, M.J., and W.A. Patterson III. 2007. Characterizing canopy fuels to predict fire behavior in pitch pine stands. Northern Journal of Applied Forestry 24 (1): 65-70. https://doi.org/10.1093/njaf/24.1.65.

Engelstad, P.S., M. Falkowski, P.T. Wolter, A. Poznanovic, and P. Johnson. 2019. Estimating canopy fuel attributes from low-density LiDAR. Fire 2 (3): 38. https://doi.org/10.3390/fire2030038.

Erdody, T.L., and L.M. Moskal. 2010. Fusion of LiDAR and imagery for estimating forest canopy fuels. Remote Sensing of Environment 114 (4): 725-737. https:// doi.org/10.1016/j.rse.2009.11.002.

Fassnacht, K.S., S.T. Gower, J.M. Norman, and R.E. McMurtric. 1994. A comparison of optical and direct methods for estimating foliage surface area index in forests. Agricultural and Forest Meteorology 71 (1-2): 183-207. https://doi.org/1 0.1016/0168-1923(94)90107-4.

Fernández-Alonso, J.M., L. Alberdi, J.G. Álvarez-González, J.A. Vega, L. Cañellas, and A. D. Ruiz-González. 2013. Canopy fuel characteristics in relation to crown fire potential in pine stands: Analysis, modelling and classification. European Journal of Forest Research 132 (2): 363-377. https://doi.org/10.1007/s10342-012-0680-z.

Finney, M.A. 1998. FARSITE: Fire area simulator-model development and evaluation. USDA Forest Service RMRS-RP-4. Fort Collins: USDA Forest Service, Rocky Mountain Research Station. https://doi.org/10.2737/RMRS-RP-4.

Frelich, L.E., and P.B. Reich. 1995. Spatial patterns and succession in a Minnesota southern-boreal forest. Ecological Monographs 65 (3): 325-346. https://doi. org/10.2307/2937063.
Geladi, P., and B.R. Kowalski. 1986. Partial least-squares regression: A tutorial. Analytica Chimica Acta 185: 1-17. https://doi.org/10.1016/0003-2670(86)80028-9.

Gong, G. 1986. Cross-validation, the jackknife, and the bootstrap: Excess error estimation in forward logistic regression. Journal of the American Statistical Association 81 (393): 108-113. https://doi.org/10.1080/016214 59.1986.10478245.

Gower, S.T., and J.M. Norman. 1991. Rapid estimation of leaf area index in conifer and broad-leaf plantations. Ecology 72 (5): 1896-1900. https://doi.org/10.23 07/1940988.

Gray, K.L., and E.D. Reinhardt. 2003. Analysis of algorithms for predicting canopy fuel. In Proceedings of the Second International Wildland Fire Ecology and Fire Management Congress and Fifth Symposium on Fire and Forest Meteorology. Orlando: American Meteorological Society.

Heinselman, M.L. 1973. Fire in the virgin forests of the Boundary Waters Canoe Area, Minnesota. Quaternary Research 3 (3): 329-382. https://doi.org/10.1016/ 0033-5894(73)90003-3.

Huang, X., B. Ziniti, N. Torbick, and M.J. Ducey. 2018. Assessment of forest above ground biomass estimation using multi-temporal C-band sentinel-1 and polarimetric L-band PALSAR-2 data. Remote Sensing 10 (9): 1424. https://doi. org/10.3390/rs10091424.

Imhoff, M.L. 1995. A theoretical analysis of the effect of forest structure on synthetic aperture radar backscatter and the remote sensing of biomass. IEEE Transactions on Geoscience and Remote Sensing 33 (2): 341-351. https://doi. org/10.1109/TGRS.1995.8746015

Jakubowksi, M.K., Q. Guo, B. Collins, S. Stephens, and M. Kelly. 2013. Predicting surface fuel models and fuel metrics using Lidar and CIR imagery in a dense, mountainous forest. Photogrammetric Engineering \& Remote Sensing 79 (1): 37-49. https://doi.org/10.14358/PERS.79.1.37.

Jamali, A., P. Boguslawski, and C.M. Gold. 2014. Trimble LaserAce 1000 accuracy evaluation for indoor data acquisition. In The XXV FIG International Congress 2014: engaging the challenges, enhancing the relevance. Copenhagen: International Federation of Surveyors, FIG. ISBN 978-87-928532-1-9.

Joshi, N., E.T. Mitchard, M. Brolly, J. Schumacher, A. Fernández-Landa, V.K. Johannsen, and R. Fensholt. 2017. Understanding 'saturation' of radar signals over forests. Scientific Reports 7 (1): 3505. https://doi.org/10.1038/s41598-017-03469-3.

Keane, R.E., R.E. Burgan, and J.W. van Wagtendonk. 2001. Mapping wildland fuel for fire management across multiple scales: Integrating remote sensing, GIS, and biophysical modeling. International Journal of Wildland Fire 10 (4): 301 319. https://doi.org/10.1071/WF01028.

Keane, R.E., T. Frescino, M.C. Reeves, and J.L. Long. 2006. Mapping wildland fuel across large regions for the LANDFIRE Prototype Project. In The LANDFIRE Prototype Project: Nationally consistent and locally relevant geospatial data for wildland fire management, technical edited by M.G. Rollins and C.K. Frame, 367-396. USDA Forest Service General Technical Report RMRS-GTR-175. Fort Collins: USDA Forest Service, Rocky Mountain Research Station.

Keane, R.E., E.D. Reinhardt, J. Scott, K. Gray, and J. Reardon. 2005. Estimating forest canopy bulk density using six indirect methods. Canadian Journal of Forest Research 35 (3): 724-739. https://doi.org/10.1139/×04-213.

Keane, R.E., K.C. Ryan, T.T. Veblen, C.D. Allen, J. Logan, and B. Hawkes. 2002. The cascading effects of fire exclusion in the Rocky Mountains. In USDA Forest Service General Technical Report RMRS-GTR-91. Fort Collins: USDA Forest Service, Rocky Mountain Research Station. https://doi.org/10.2737/RMRS-GTR-91.

Kellndorfer, J., W. Walker, L. Pierce, C. Dobson, J.A. Fites, C. Hunsaker, J. Vona, and M. Clutter. 2004. Vegetation height estimation from shuttle radar topography mission and national elevation datasets. Remote Sensing of Environment 93 (3): 339-358. https://doi.org/10.1016/j.rse.2004.07.017.

Krasnow, K., T. Schoennagel, and T.T. Veblen. 2009. Forest fuel mapping and evaluation of LANDFIRE fuel maps in Boulder County, Colorado, USA. Forest Ecology and Management 257 (7): 1603-1612. https://doi.org/10.1016/j. foreco.2009.01.020

Kutner, M.H., C.J. Nachtsheim, J. Neter, and W. Li. 2005. Applied linear statistical models. Vol. 5. Boston: McGraw-Hill Irwin.

LANDFIRE. 2011. LANDFIRE product assessment: eastern milestone super zone analysis and report. Sioux Falls: US Department of the Interior, Geological Survey, EROS Data Center.

Le Toan, T., A. Beaudoin, J. Riom, and D. Guyon. 1992. Relating forest biomass to SAR data. IEEE Transactions on Geoscience and Remote Sensing 30 (2): 403411. https://doi.org/10.1109/36.134089.

Légaré, S., Y. Bergeron, and D. Paré. 2002. Influence of forest composition on understory cover in boreal mixedwood forests of western Quebec. Silva Fennica 36 (1): 353-366. https://doi.org/10.14214/sf.567. 
LI-COR. 2011. LAl-2200 Plant canopy analyzer: instruction manual. Lincoln: LI-COR Inc..

Lutes, D.C. 2020. FuelCalc 1.7 Users Guide. Missoula: USDA Forest Service, Rocky Mountain Research Station, Fire Modeling Institute.

Masek, J.G., E.F. Vermote, N.E. Saleous, R. Wolfe, F.G. Hall, K.F. Huemmrich, and T.K. Lim. 2006. A Landsat surface reflectance dataset for North America, 19902000. IEEE Geoscience and Remote Sensing Letters 3 (1): 68-72. https://doi. org/10.1109/LGRS.2005.857030.

Messier, C., S. Parent, and Y. Bergeron. 1998. Effects of overstory and understory vegetation on the understory light environment in mixed boreal forests. Journal of Vegetation Science 9 (4): 511-520. https://doi.org/10.2307/3237266.

MNGAC [Minnesota Geospatial Advisory Council]. 2020. Draft Minnesota State Lidar Plan, Remotely Sensed Data Acquisition Group. https://storymaps.arcgis. com/stories/980394f96f894980a35c6758653bb5ab

Müller, R., and P. Büttner. 1994. A critical discussion of intraclass correlation coefficients. Statistics in Medicine 13 (23-24): 2465-2476. https://doi.org/10.1 002/sim.4780132310.

Norman, J.M., and J.M. Welles. 1983. Radiative transfer in an array of canopies 1. Agronomy Journal 75 (3): 481-488. https://doi.org/10.2134/agronj1983.00021 $962007500030016 x$

Paletto, A., and V. Tosi. 2009. Forest canopy cover and canopy closure: Comparison of assessment techniques. European Journal of Forest Research 128 (3): 265-272. https://doi.org/10.1007/s10342-009-0262-x.

Perala, D.A., and D.H. Alban. 1994. Allometric biomass estimators for aspendominated ecosystems in the upper Great Lakes. USDA Forest Service Research Paper NC-314. St. Paul: USDA Forest Service, North Central Forest Experiment Station. https://doi.org/10.2737/NC-RP-314.

Perry, S.G., A.B. Fraser, D.W. Thomson, and J.M. Norman. 1988. Indirect sensing of plant canopy structure with simple radiation measurements. Agricultural and Forest Meteorology 42 (2-3): 255-278. https://doi.org/10.1016/0168-1923 (88)90082-2.

Pulliainen, J.T., L. Kurvonen, and M.T. Hallikainen. 1999. Multitemporal behavior of $\mathrm{L}$ - and C-band SAR observations of boreal forests. IEEE Transactions on Geoscience and Remote Sensing 37 (2): 927-937. https://doi.org/10.1109/36. 752211.

Rauste, Y. 2005. Multi-temporal JERS SAR data in boreal forest biomass mapping. Remote Sensing of Environment 97 (2): 263-275. https://doi.org/10.1016/j.rse.2 005.05.002.

Reeves, M.C., K.C. Ryan, M.G. Rollins, and T.G. Thompson. 2009. Spatial fuel data products of the LANDFIRE project. International Journal of Wildland Fire 18 (3): 250-267. https://doi.org/10.1071/WF08086.

Reinhardt, E., D. Lutes, and J. Scott. 2006. FuelCalc: A method for estimating fuel characteristics. 2006. In Fuels management-how to measure success: Conference proceedings, compiled by P.L. Andrews, and B.W. Butler, 273-282. USDA Forest Service Proceedings RMRS-P-41. Fort Collins: USDA Forest Service, Rocky Mountain Research Station.

Rich, R.L., L.E. Frelich, and P.B. Reich. 2007. Wind-throw mortality in the southern boreal forest: Effects of species, diameter and stand age. Journal of Ecology 95 (6): 1261-1273. https://doi.org/10.1111/j.1365-2745.2007.01301.x.

Rollins, M.G. 2009. LANDFIRE: A nationally consistent vegetation, wildland fire, and fuel assessment. International Journal Wildland Fire 18 (3): 235-249. https://doi.org/10.1071/WF08088.

Rothermel, R.C. 1991. Predicting behavior and size of crown fires in the Northern Rocky Mountains. In USDA Forest Service Research Paper RP-438. Ogden: USDA Forest Service Intermountain Forest and Range Experiment Station. https:// doi.org/10.2737/INT-RP-438.

Rouse, J.W., R.H. Haas, J.A. Schell, and D.W. Deering. 1974. Monitoring vegetation systems in the Great Plains with ERTS. In Proceedings of the 3rd ERTS Symposium. Pages 309-317 in NASA Goddard Space Flight Center 3d ERTS-1 Symposium, Volume 1, Section A. Washington D.C.: U.S. Government Printing Office.

Saatchi, S., K. Halligan, D.G. Despain, and R.L. Crabtree. 2007. Estimation of forest fuel load from radar remote sensing. IEEE Transactions on Geoscience and Remote Sensing 45 (6): 1726-1740. https://doi.org/10.1109/TGRS.2006.887002.

Sadeghi, Y., B. St-Onge, B. Leblon, J.F. Prieur, and M. Simard. 2018. Mapping boreal forest biomass from a SRTM and TanDEM-X based on canopy height model and Landsat spectral indices. International Journal of Applied Earth Observation and Geoinformation 68: 202-213. https://doi.org/10.1016/j.jag.2017.12.004.

Sader, S.A. 1987. Forest biomass, canopy structure, and species composition relationships with multipolarization L-band synthetic aperture radar data. Photogrammetric Engineering \& Remote Sensing 53 (2): 193-202.
Sayn-Wittgenstein, L. 1961. Phenological aids to tree species identification on air photographs. Technical Note No. 104. Ottawa: Forest Research Branch, Canada Department of Forestry.

Schlund, M., D. Baron, P. Magdon, and S. Erasmi. 2019. Canopy penetration depth estimation with TanDEM-X and its compensation in temperate forests. ISPRS Journal of Photogrammetry and Remote Sensing 147: 232-241. https://doi. org/10.1016/j.isprsjprs.2018.11.021.

Schwartz, G. 1978. Estimating the dimension of a model. The Annals of Statistics 6 (2): 461-464. https://doi.org/10.1214/aos/1176344136.

Scott, J. 2008. Review and assessment of LANDFIRE canopy fuel mapping procedures. Landfire Bulletin. Fort Collins: U.S. Department of Agriculture, Forest Service, Rocky Mountain Research Station. 22 p. Available from https://landfire.cr.usgs.gov/documents/LANDFIRE_Canopyfuels_and_Sea mlines_ReviewScott.pdf.

Scott, J.H. 1999. NEXUS: A system for assessing crown fire hazard. Fire Management Notes 59: 21-24.

Scott, J.H., and E.D. Reinhardt. 2005. Stereo photo guide for estimating canopy fuel characteristics in conifer stands. USDA Forest Service General Technical Report RMRS-GTR-145. Fort Collins: USDA Forest Service, Rocky Mountain Research Station. https://doi.org/10.2737/RMRS-GTR-145.

Sexton, J.O., T. Bax, T.P. Siqueira, J.J. Swenson, and S. Hensley. 2009. A comparison of lidar, radar, and field measurements of canopy height in pine and hardwood forests of southeastern North America. Forest Ecology and Management 257 (3): 1136-1147. https://doi.org/10.1016/j.foreco.2008.11.022.

Singh, A., A.R. Jakubowski, I. Chidister, and P.A. Townsend. 2013. A MODIS approach to predicting stream water quality in Wisconsin. Remote Sensing of Environment 128: 74-86. https://doi.org/10.1016/..rse.2012.10.001.

Song, C., C.E. Woodcock, K.C. Seto, M.P. Lenney, and S.A. Macomber. 2001. Classification and change detection using Landsat TM data: When and how to correct atmospheric effects? Remote sensing of Environment 75 (2): 230244. https://doi.org/10.1016/S0034-4257(00)00169-3.

Stenberg, P., S. Linder, H. Smolander, and J. Flower-Ellis. 1994. Performance of the LAl-2000 plant canopy analyzer in estimating leaf area index of some Scots pine stands. Tree Physiology 14 (7-8-9): 981-995. https://doi.org/10.1093/ treephys/14.7-8-9.981.

Thapa, B., P.T. Wolter, B.R. Sturtevant, and P.A. Townsend. 2020. Reconstructing past forest composition and abundance by using archived Landsat and national forest inventory data. International Journal of Remote Sensing 41 (10): 4022-4056. https://doi.org/10.1080/01431161.2019.1711245.

Tukey, J. 1953. Multiple comparisons. Journal of the American Statistical Association 48 (264): 624-625.

USDI National Park Service. 2003. Fire monitoring handbook. Boise: Fire Management Program Center, National Interagency Fire Center.

Ustin, S.L. 2004. Remote sensing instruments: Past and present. In Manual of remote sensing, remote sensing for natural resource management and environmental monitoring (volume 4). Hoboken: Wiley.

Van Hooser, D.D. 1983. Whole tree volume estimates for the Rocky Mountain States Nol. 29). USDA Forest Service Resource bulletin INT-29. Ogden: USDA Intermountain Forest and Range Experiment Station.

Van Wagner, C.E. 1977. Conditions for the start and spread of crownfire. Canadian Journal of Forest Research 7 (1): 23-24. https://doi.org/10.1139/x77004

Vermote, E.F., N. El Saleous, C.O. Justice, Y.J. Kaufman, J.L. Privette, L. Remer, and D. Tanre. 1997. Atmospheric correction of visible to middle-infrared EOSMODIS data over land surfaces: Background, operational algorithm and validation. Journal of Geophysical Research: Atmospheres 102 (D14): 1713117141. https://doi.org/10.1029/97JD00201.

Vogelmann, J.E., and B.N. Rock. 1988. Assessing forest damage in high-elevation coniferous forests in Vermont and New Hampshire using Thematic Mapper data. Remote Sensing of Environment 24 (2): 227-246. https://doi.org/10.1016/ 0034-4257(88)90027-2.

Wang, Y., F.W. Davis, and J.M. Melack. 1993. Simulated and observed backscatter at $P_{-}, L_{-}$, and $C$-bands from ponderosa pine stands. IEEE Transactions on Geoscience and Remote Sensing 31 (4): 871-879. https:/doi.org/10.1109/36.239910.

Wang, Y., F.W. Davis, J.M. Melack, E.S. Kasischke, and N.L. Christensen Jr. 1995. The effects of changes in forest biomass on radar backscatter from tree canopies. Remote Sensing 16 (3): 503-513. https://doi.org/10.1080/01431169508954415.

Westfall, P.H. 2014. Kurtosis as peakedness, 1905-2014. RIP. The American Statistician 68 (3): 191-195. https://doi.org/10.1080/00031305.2014.917055.

White, J.D., S.W. Running, R. Nemani, R.E. Keane, and K.C. Ryan. 1997. Measurement and remote sensing of LAl in Rocky Mountain montane 
ecosystems. Canadian Journal of Forest Research 27 (11): 1714-1727. https:/ doi.org/10.1139/x97-142.

Wolter, P.T., E.A. Berkley, S.D. Peckham, A. Singh, and P.A. Townsend. 2012. Exploiting tree shadows on snow for estimating forest basal area using Landsat data. Remote Sensing of Environment 121: 69-79. https://doi.org/10.1 016/.rse.2012.01.008.

Wolter, P.T., D.J. Mladenoff, G.E. Host, and T.R. Crow. 1995. Improved forest classification in the northern Lake State using multi-temporal Landsat imagery. Photogrammetric Engineering \& Remote Sensing 61 (9): 1129-1143.

Wolter, P.T., and P.A. Townsend. 2011. Multi-sensor data fusion for estimating forest species composition and abundance in northern Minnesota. Remote Sensing of Environment 115 (2): 671-691. https://doi.org/10.1016/j.rse.2010.10. 010.

Wolter, P.T., P.A. Townsend, and B.R. Sturtevant. 2009. Estimation of forest structural parameters using 5 and 10 meter SPOT-5 satellite data. Remote Sensing of Environment 113 (9): 2019-2036. https://doi.org/10.1016/j.rse.2009. 05.009.

Wolter, P.T., P.A. Townsend, B.R. Sturtevant, and C.C. Kingdon. 2008. Remote sensing of the distribution and abundance of host species for spruce budworm in Northern Minnesota and Ontario. Remote Sensing of Environment 112 (10): 3971-3982. https://doi.org/10.1016/j.rse.2008.07.005.

Wolter, P.T., and M.A. White. 2002. Recent forest cover type transitions and landscape structural changes in northeast Minnesota, USA. Landscape Ecology 17 (2): 133-155. https://doi.org/10.1023/A:1016522509857.

Zavitkovski, J. 1976. Ground vegetation biomass, production, and efficiency of energy utilization in some northern Wisconsin forest ecosystems. Ecology 57 (4): 694-706. https://doi.org/10.2307/1936183.

\section{Publisher's Note}

Springer Nature remains neutral with regard to jurisdictional claims in published maps and institutional affiliations.

\section{Submit your manuscript to a SpringerOpen ${ }^{\circ}$ journal and benefit from:}

- Convenient online submission

- Rigorous peer review

- Open access: articles freely available online

High visibility within the field

- Retaining the copyright to your article

Submit your next manuscript at $\boldsymbol{\nabla}$ springeropen.com 